\title{
Exchange Rate Exposure : International Evidence from Daily Firm-Level Data
}

\author{
Bang Nam Jeon \\ Drexel University, Philadelphia, United States \\ Dazhi Zheng \\ West Chester University of Pennsylvania, West Chester, United States \\ Lei Zhu \\ West Chester University of Pennsylvania, West Chester, United States
}

\begin{abstract}
This paper examines impact of changes in the foreign exchange rate on firms' stock returns in global markets. Using daily firm-level data for 14 international markets from January 2000 to December 2011, we find evidence that changes in the trade-weighted multilateral exchange rate systematically impact individual firms' stock returns for all seven emerging markets and some advanced economies. Controlling for price factors such as market risk premium, Fama-French factors, the momentum, and the liquidity factor, we correct the upward bias of the estimation. Stocks in export-oriented economies are shown to considerably benefit from local currency depreciation. Further, in emerging markets, exchange rate movements affect larger firms with more intense global connections, but in advanced markets, they affect smaller firms with limited access to hedging to a larger extent. Long-run equilibrium relationships between stock

\footnotetext{
* Corresponding Author: Bang Nam Jeon; School of Economics, Bennett S. LeBow College of Business, Drexel University, 32nd and Market Streets, Philadelphia, PA 19104, USA, Tel: +16102203461, Fax: +12158956156, E-mail: jeonbana@drexel.edu.

Co-Authors: Dazhi Zheng; Department of Economics and Finance, College of Business \& Public Management, West Chester University of Pennsylvania, West Chester, PA 19383, USA, Tel: +16104304635, Fax:+16104362592, E-mail: dzheng@wcupa.edu.

Lei Zhu; Department of Economics and Finance, College of Business \& Public Management, West Chester University of Pennsylvania, West Chester, PA 19383, USA, Tel: +16104305671, Fax:+16104362592, E-mail: lzhu@wcupa.edu.
} 
markets and foreign exchange markets become stronger since the global financial crisis of 2008 2009.

JEL Classifications: G12, G15, F31

Keywords: Exchange Rate Exposure, International Stock Markets, Emerging Markets

\section{Introduction}

As businesses are increasingly interconnected globally, foreign exchange rate movements have been perceived as one of the most important sources of uncertainty to firms' cash flows and profitability. Financial theory predicts that changes in foreign exchange rates affect the value of firms. However, empirical studies have only found weak evidence of systematic exchange rate exposure. While extensive research has examined the relationship between exchange rate changes and stock returns using different samples and methodologies, the majority of these studies have found that only $10 \% \sim 25 \%$ of firms are directly exposed to foreign exchange rate risk. ${ }^{1}$

The theoretical literature argues that a multinational firm with export sales and foreign competition should be subject to foreign exchange rate risk. The depreciation of the local currency makes the product more affordable to foreign consumers and increases foreign sales. Simultaneously, the cost of production rises for firms using imported intermediate goods, leading to a lower profit. In addition, even domestic firms that are not engaged in international activities may face foreign competition or are indirectly affected by exchange rate movements as they may have business more or less interacted with multinational companies. The empirical literature focusing on firms in the United States (US) has identified a weak linkage between exchange rate fluctuations and stock returns. For example, Jorion (1990) examined 287 US multinational firms and found that only $5.2 \%$ of their sample shows significant foreign exchange rate exposure. Amihud (1994) found no evidence of contemporaneous exposure for 32 US leading exporting companies. In addition, Choi and Prasad (1995) employed trade-weighted exchange rates and found a significant impact of foreign exchange rate movements on stock price

\footnotetext{
See, for example, Bartram and Bodnar (2007).
} 
for only $14.9 \%$ of US firms.

While the estimates for the exchange rate exposure of US firms are economically small and statistically less significant, research outside the US provides similar results. For example, $\mathrm{He}$ and $\mathrm{Ng}$ (1998) found that $26.3 \%$ of 171 Japanese multinational firms exhibit significant exchange rate exposure. Studies in other countries have suggested that exchange rate movements constitute only a small portion of the variation in stock returns (Nydal 1999, Bartram 2004).

Some studies have included multiple countries to investigate cross-country variations in exchange rate exposure. Dominguez and Tesar (2001a) examined exchange rate exposure in eight countries over 18 years at both firm and industry levels. They found a considerable linkage between foreign activity and exchange rate exposure. In contrast, Griffin and Stulz (2001) conducted cross-country industry analysis and presented evidence that foreign exchange exposure is small. Dominguez and Tesar (2006) extended their previous study of eight countries and demonstrated that exchange rate exposure is larger for small firms but is linked to foreign activity. Bartram and Karolyi (2006) examined the effect of introducing the euro in 18 European countries, the US and Japan, and found only small exposure for those countries. Using data from 18 developed markets, Doidge et al. (2006) reported that foreign exchange rate exposure is economically and statistically small for individual firms.

Another strand of studies has explored possible reasons to explain the low significance of exchange rate exposure. Francis et al. (2008) applied a conditional asset pricing model to 36 US industries and presented evidence of a time-varying currency exposure premium. Furthermore, they pointed out that the failure to find significant currency risk at the industry level is due to methodological weaknesses, not foreign exchange risk hedging. Bartram and Bodnar (2012) argued that the relationship between exchange rate movement and stock returns should be conditioned on the realized changes in the exchange rate. Using a large sample of non-financial firms from 37 countries, they demonstrated that the exposure effect ranges from $1.2 \%$ to $3.3 \%$ per unit of currency change for their entire sample. In addition, they found that emerging markets are more significantly exposed to foreign exchange risk than advanced markets.

To fill the gap in the mixed findings of the aforementioned studies, we take extended approaches to re-examine how changes in exchange rate affect stock returns in both advanced and emerging markets on a daily basis. First, we use large sample firm-level data for our analysis. Numerous previous studies have focused on multinationals or exportoriented firms. Since those firms maintain large trading volumes, they are more likely to 
be exposed to exchange rate risks; the limited sample may not reflect the exchange rate exposure for the whole market. According to financial theories, exchange rate movements should have a measurable effect on firms, even those not involved in international business due to cross-firm competition and indirect costs. Therefore, to examine the systematic exchange-rate exposure at the disaggregated level, we use intensive firm-level data for each economy in our sample. We include an average of 1,021 firms from each of 14 national markets, covering local firms as well as multinationals.

Second, we use high-frequency (daily) data to construct firm-level stock returns and multilateral foreign exchange rates. The trade-weighted exchange rate has been used in the existing literature mostly on an annual or monthly basis. Since shocks from foreign exchange markets sometimes last a short period and may be absorbed quickly, annual or monthly data fail to effectively reveal the sensitivity of stock prices to exchange rate fluctuations. We believe that high-frequency data should be able to capture the effect of exchange rate exposure much more accurately than low-frequency data.

Third, we extend the analysis to both advanced and emerging economies. Extant studies have examined the exchange rate exposure effect mainly for the US or individual markets, and fewer studies have extended to international markets. We select firms from 14 economies, which include the most influential markets and dominant global traders, such as the G7 countries (Canada, France, Germany, Italy, Japan, the United Kingdom (UK), and the US), as well as seven emerging markets, including four Asian markets (Hong Kong, Singapore, South Korea, and Taiwan) and three Latin American markets (Argentina, Brazil, and Mexico).

Fourth, we conduct portfolio analysis to further examine the role of exchange rate movements in determining stock returns and/or generating firms' value. We evaluate the exchange rate exposure effect in firms according to exchange rate variation, different market values, and in different industries - traded-goods versus non-traded goods industries.

Finally, in examining the relationship between exchange rate changes and stock returns, we include some of the important price factors, such as Fama-French (1993) variables, the momentum factor (Carhart 1997), and the liquidity variable as additional control variables in our extended exchange rate exposure model.

Using daily firm-level data for 14 international markets from January 2000 to December 2011, we find evidence that changes in trade-weighted multilateral exchange rates systematically affect individual firms' stock returns for all seven emerging markets and some advanced economies. Furthermore, we find that the results are more robust when we include price factors such as Fama-French-Carhart variables and the liquidity 
variable. We further examine the impact of exchange rate exposure on various portfolio sets, composed of different firm size and industries at the firm-specific level, in a highfrequency context. In addition, we find long-run equilibrium relations between national stock markets and foreign exchange markets during the post-crisis period after 2008, implying an increasing trend of exchange rate exposures and economic integration in the global economy.

The paper is organized as follows: Section II presents the empirical model. Section III describes the data. Section IV reports and discusses empirical results from estimations of the baseline and extended models. Section V concludes the study.

\section{Empirical Models}

\section{A. The exchange rate exposure model}

Following Adler and Dumas (1984) and Jorion (1990), we construct a baseline model to test the impact of exchange rate movement on individual firms' excess stock returns:

$$
R_{i, t}-r_{f, t}=\beta_{0}+\beta_{1} R_{F X, t}+\beta_{2} M K T R P_{t}+\varepsilon_{i, t}
$$

where $R_{i, t}$ is the daily stock return for firm $i . r_{f, t}$ denotes the daily risk-free rate. $R_{F X, t}$ is the change in the weighed exchange rate variable, measured as the foreign currency price of the home currency. Thus, the positive value of $R_{F X, t}$ indicates home currency appreciation. MKTRP denotes the domestic market risk premium calculated as $\left(R_{m, t}\right.$ $\left.-r_{f, t}\right)$, where $R_{m, t}$ is the domestic stock market index return. We use it as a market factor to control for the overall stock market trend in deriving the exchange rate-stock return nexus at the individual firm level.

In the estimation, the coefficients of $R_{F X, t}, \beta_{1}$, measure the exchange rate exposure of individual firms in the host country. If the restriction of $\beta_{1}=0$ is rejected, it implies that there is significant exchange rate exposure. In other words, changes in the exchange rate can systematically affect excess stock returns. The sign of $\beta_{1}$ can be either positive or negative depending on the net exposed asset (long) and liability (short) position of firm 
$i{ }^{2}$ The position status will reflect if the firm is a net exporter vs. importer or experiences inward vs. outward cash flows.

\section{B. The extended model}

Fama and French (1993) propose that besides the market risk premium $\left(R_{m}-r_{f}\right)$, the size factor, which is measured as the average return of the small capitalization portfolio minus that of the large capitalization portfolio $(S M B)$, and the value factor, which is measured as the average return of the value portfolio minus that of the growth portfolio $(H M L)$, explain substantial cross-sectional stock return variation. ${ }^{3}$ Carhart (1997) finds that in addition to $S M B$ and $H M L$, buying winner stocks and selling loser stocks constructs a profitable strategy, and a momentum factor $(M O M)$ is often used together with $S M B$ and $H M L$ in the stock market asset pricing model. Therefore, following Fama and French (1993) and Carhart (1997), we construct daily SMB, HML, and MOM for all 14 international markets. ${ }^{4}$ In addition, stock liquidity has been documented as an important price factor. ${ }^{5}$ Following Amihud (2002), we calculate the monthly stock illiquidity measure based on the following equation:

$$
\text { Illiq }_{i, m}=\frac{1}{D_{i, m}} \sum_{t=1}^{D_{i, m}} \frac{\left|R_{i, m, d}\right|}{\operatorname{VOLD_{i,m,d}}}
$$

where $D_{i, m}$ is the number of trading days of stock $i$ for a month, $R_{i, m, d}$ denotes the daily return for stock $i$, and $V O L D_{i, m, d}$ is the dollar trading volume for stock $i$. In line with the Fama-French-Carhart risk factors, we construct the liquidity risk factor by taking the average return of the most illiquid portfolio minus that of the least illiquid portfolio (Illiq).

After including these four widely used stock market price factors as described above, our extended exchange rate exposure model can be specified as follows:

$$
R_{i, t}-r_{f, t}=\beta_{0}+\beta_{1} R_{F X, t}+\beta_{2} M K T R P_{t}+\sum_{s=1}^{S} \gamma_{s} Z_{s, t}+\varepsilon_{i, t}
$$

\footnotetext{
${ }^{2}$ For detailed discussion on this, see Pantzalis (2001), and footnote 5 in Moore and Wang (2014).

${ }^{3}$ See, for example, Miles and Timmermann (1996)'s finding in the UK market.

${ }^{4}$ Details concerning the formation of Fama-French factors, the momentum factor and liquidity portfolios for each country are provided in Appendix 4.

${ }^{5}$ See, for example, Pastor and Stambaugh (2003) and Acharya and Pedersen (2005)
} 
where the variables are defined as per the baseline model in Equation (1); $Z_{s, t}$ denotes a set of additional control variables absent in the baseline model. These comprise four local market price factors: $S M B, H M L, M O M$, and Illiq. $\gamma_{s}$ represents the coefficients of these four variables. The rejection of $\gamma_{s}=0$ is consistent with that in previous studies, indicating that the Fama-French-Carhart factors and the illiquidity variable are important stock pricing factors.

In the empirical analysis, to address the possible econometric issues, we use the cluster analysis to take care of the cross-sectional correlation of residuals in pooled regressions and the Newey-West method to yield consistent estimators.

\section{Data}

\section{A. Exchange rate data}

The bilateral real exchange rate has been used widely in the literature. However, when examining international investments, analysis using only bilateral exchange rates may be misleading. Bilateral exchange rates ignore home country's multi-country interactions with different trading partners. In order to assess the competitiveness of the US dollar in the global economy, both the US Federal Reserve and International Monetary Fund created trade-weighted effective exchange rate indices (Leahy 1998). We adopt the method used by the Federal Reserve to construct trade-weighted exchange rates on a daily basis for all 14 markets in our sample. Daily exchange rates are collected from the FRED database compiled by the Federal Reserve at St. Louis. Argentina's exchange rates are obtained from DataStream International. Monthly consumer price index (CPI) data are from International Financial Statistics. We collect monthly bilateral trade data from the Organization for Economic Cooperation and Development (OECD) Monthly Statistics of International Trade database.

Due to data availability, currently we only use bilateral trade among those 14 advanced and emerging economies to construct the weights. Appendix 1 presents the average shares of trading, exports and imports, of each economy with their trading partners. We construct two different measures of trade-weighted exchange rates. For the export-weighted exchange rate of country $i$, we use the share of partner country $k$ 
in country $i$ 's exports to all trading partners as the weight. Using the share of imports from partner country $k$ to country $i$, we obtain the import-weighted exchange rates. The equation calculating the exchange rate of country $i$ is specified as follows:

$$
F X_{i, t}=\sum_{k} w_{i k, t} \times r e r_{i k, t}
$$

where $F X_{\mathrm{i}, \mathrm{t}}$ denotes a trade-weighted exchange rate, and $r e r_{i k, t}$ is the daily bilateral real exchange rate between country $i$ and its trading partner $k$ at time $t$, measured as the price of the home currency in foreign currency. The weights, $w_{i k, t}$, are based on monthly bilateral trade data that vary over time to reflect changing trading patterns.

\section{B. Stock market data}

We collect stock price, trading volume, price-to-book ratio, and market capitalization data for both individual firms and market indices from the 14 advanced and emerging markets: Canada, France, Germany, Italy, Japan, the UK, the US, Hong Kong, Singapore, South Korea, Taiwan, Argentina, Brazil, and Mexico. The data cover the period from January 1, 2000, to December 31, 2011, and are taken from DataStream international for all markets except the US, which are taken from the Center for Research in Security Prices (CRSP) and Compustat databases. We use monthly data to construct Fama-French and liquidity portfolios for each market. The daily stock return is calculated as $R_{t}=100 \times\left(\log \left(P_{t}\right)-\log \left(P_{t-1}\right)\right)$, where $P_{t}$ denotes the daily stock prices or indices.

Appendix 2 presents average daily stock returns for all 14 economies by year. We divide them into two groups: the G7 countries as advanced markets and the remaining economies as emerging markets. The samples range from an average of 71 firms per year for Argentina, which is the smallest among 14 markets, to an average of 7,505 firms for the US, the market with the largest number of firms. In general, more firms are listed in advanced markets than those listed in emerging markets. Japan and the UK have more than 1,000 firms per year on average. The average number of firms in the other four advanced markets is in the three-digit range almost every year; this is comparable with the number of firms in the four Asian Tigers (Hong Kong, Singapore, South Korea, and Taiwan), which ranges between 522 for Singapore and 923 for Hong Kong. Argentina, Brazil, and Mexico are relatively small markets, with approximately 100 or fewer firms. 
Appendix 2 shows that the US earns the highest average annual returns and Canada ranks second among the advanced markets, whereas Japan and Italy have negative average returns over our sample period of 2000 2011. The average returns in the seven emerging markets are all positive, with Mexico at the top, followed by Argentina and Brazil. Overall, the mean return volatilities in the seven emerging markets are higher than those in the seven advanced markets. The highest volatility is found in South Korea, and the lowest volatility is found in Canada.

If we compare stock market performance by year, the best years with positive average returns for all markets are from 2003 to 2007 (except the US, Japan, and Italy in 2007). For 2001 and 2002, average market returns of some economies are negative, which reflects the recession after the dot-com bubble crash. Furthermore, stock market performance has been severely impacted in 2008 when compared with that in other sample periods. Average stock returns in 2008 are negative for all 14 markets, and the absolute values of those returns are also the highest. This implies severe negative impacts of the recent global financial crisis on stock markets on a global scale. In 2009 and 2010, stock market returns picked up for most economies, benefiting from government stimulus packages and various crisis management policies. However, a downward trend in the stock market return was observed for global stock markets, including both advanced and emerging markets, in 2011 due to the spillover effects of the European sovereign debt crisis.

\section{Empirical Results}

\section{A. Estimates of exchange rate exposure}

\section{The baseline model}

We estimate the stock return-exchange rate nexus using Equation (1), where the daily stock excess return is the dependent variable. The market risk premium and daily exchange rate changes serve as the independent variables. Table 1 reports the estimation results. The coefficients on the exchange rate variables are shown to be statistically significant for all seven emerging markets and in Japan, Canada, and Italy among the advanced markets. No statistical significance is found in the US market. 


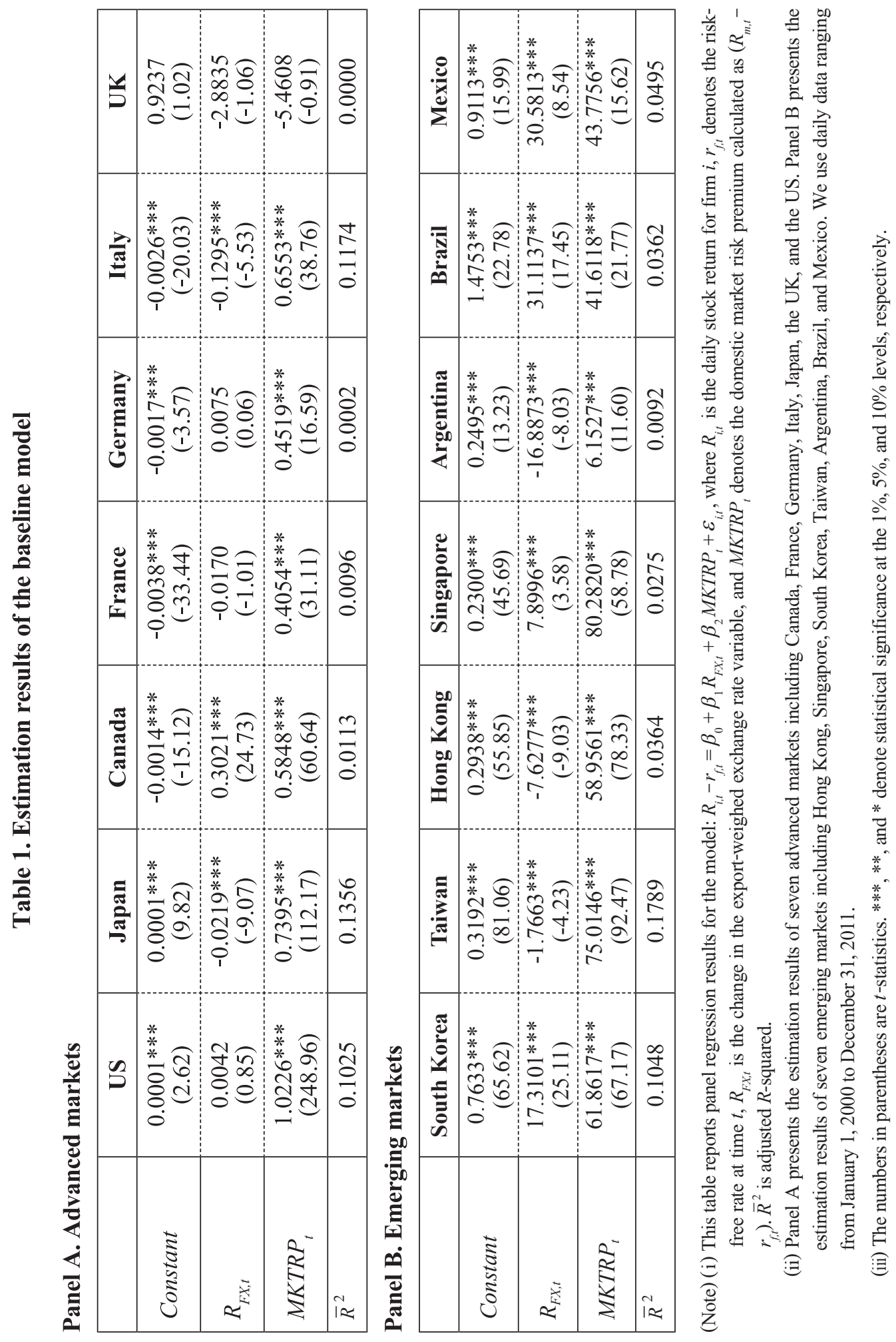


Our results indicate that although exchange rate changes do not systematically affect all US firms, it is an important factor affecting stock returns at the firm level in international markets, especially for emerging markets and some smaller advanced markets. Since most emerging markets adopted an export-led growth strategy, it is not surprising that exchange rate changes led to fluctuations in firms' stock returns. One rationale for the insignificant exchange rate exposure in France and Germany could be the use of a common currency, the euro, and active intra-eurozone trade. The absolute value of the coefficients of the changes in exchange rates is much higher in emerging markets than that in advanced markets. The high exchange rate exposure could be a contributing factor for larger fluctuations of stock prices in emerging markets.

A variation is observed in the direction of exchange rate exposure across countries. The exchange rate exposure coefficients are significantly negative for Japan, Italy, Taiwan, Hong Kong, and Argentina, indicating that a depreciation of the home currency results in an increase in stock returns. Home currency depreciation often leads to more exports and less imports in quantity and value when the Marshall-Lerner condition holds true. On the other hand, the coefficients are significantly positive for Canada, South Korea, Singapore, Brazil, and Mexico, suggesting that an appreciation of the home currency results in an increase in stock returns. Home currency appreciation may reduce the production costs of firms relying on imported intermediate goods, thereby boosting domestic production and consumer spending. The coefficients of exchange rate exposures are not statistically significant for four relatively large advanced economies, specifically the US, the UK, France, and Germany. This shows that at the aggregate level, the positive and negative effects cancel out to a large extent in these advanced economies. We further examine foreign exchange exposure effects by differentiating periods for local currency appreciation vs. depreciation in the section detailing our subsample estimations.

\section{The extended model}

To further explore the exchange rate exposure effect, we extend the baseline model by including widely used stock price factors, the Fama-French (1993) variables (SMB and $H M L$ ), the momentum variable (MOM, Carhart 1997), and the liquidity variable (Illiq, Amihud 2002). Based on the extended model, Equation (3), we adopt the following estimation equation for regression analysis: 


$$
R_{i, t}-r_{f, t}=\beta_{0}+\beta_{1} R_{F X, t}+\beta_{2} M K T R P_{t}+\gamma_{1} S M B_{t}+\gamma_{2} H M L_{t}+\gamma_{3} M O M_{t}+\gamma_{4} I l l i q_{t}+\varepsilon_{i, t}
$$

where $R_{i, t}$ is the daily stock return for firm $i, r_{f, t}$ denotes the risk-free rate, $R_{F X, t}$ is the change in the export-weighted exchange rate, and $M K T R P_{t}$ denotes the domestic market risk premium, measured as $\left(R_{m, t}-r_{f, t}\right){ }^{6} S M B_{t}$ is small market value portfolio return minus large market value portfolio return for a given day. $H M L_{t}$ is high book-to-market value portfolio return minus low book-to-market value portfolio return for a given day. $M O M_{t}$ for a given day is the winner's portfolio return in past six months minus loser's portfolio return in past six months. Illiq $q_{t}$ is the most illiquid portfolio return minus the least illiquid portfolio return at day $t$. The illiquidity measure is constructed using a methodology proposed by Amihud (2002).

Table 2 reports the estimation results of Equation (5). Overall, the results agree with those reported in Table 1. However, the absolute values of the coefficients of exchange rate changes are lower compared with those in Table 1 in most cases. ${ }^{7}$ In addition, the coefficients of pricing factors ( $S M B, H M L, M O M$, and the liquidity variable) are statistically significant for most of the 14 markets. This suggests that the baseline model estimation without controlling stock market pricing factors overestimates the role of exchange rate exposure. Specifically, the coefficients of SMB are significantly positive in 11 out of 14 markets. The coefficients of the $H M L$ risk show mixed signs and are statistically significant in 9 out of 14 economies. The coefficients of the momentum factor, $\operatorname{MOM}_{t}$, are negative and statistically significant in 7 out of 14 economies. This implies that the more returns diverge between high-return portfolio and low-return portfolio, the lower firm-level stock returns. The coefficients of illiquidity risk are significantly negative in 10 out of 14 economies, implying that the return difference between high and low illiquidity-dominated portfolios tends to affect stock returns of individual firms negatively. The results are in line with most existing literature. However, the estimation of the conventional exchange rate exposure model could be biased upwards if those price factors are missing in the estimation.

\footnotetext{
${ }^{6}$ We also run regressions based on the import-weighted exchange rate variable, but the results are similar to those based on the exportweighted exchange rate variable. The regression results based on the import-weighted exchange rate variable are available from the authors upon request.

${ }^{7}$ It is noteworthy to find that the coefficient sign on the exchange rate variable for Singapore is now reversed from positive to negative in the extended model estimation. This implies that Singapore is more akin to an export-oriented economy rather than an import-oriented economy.
} 


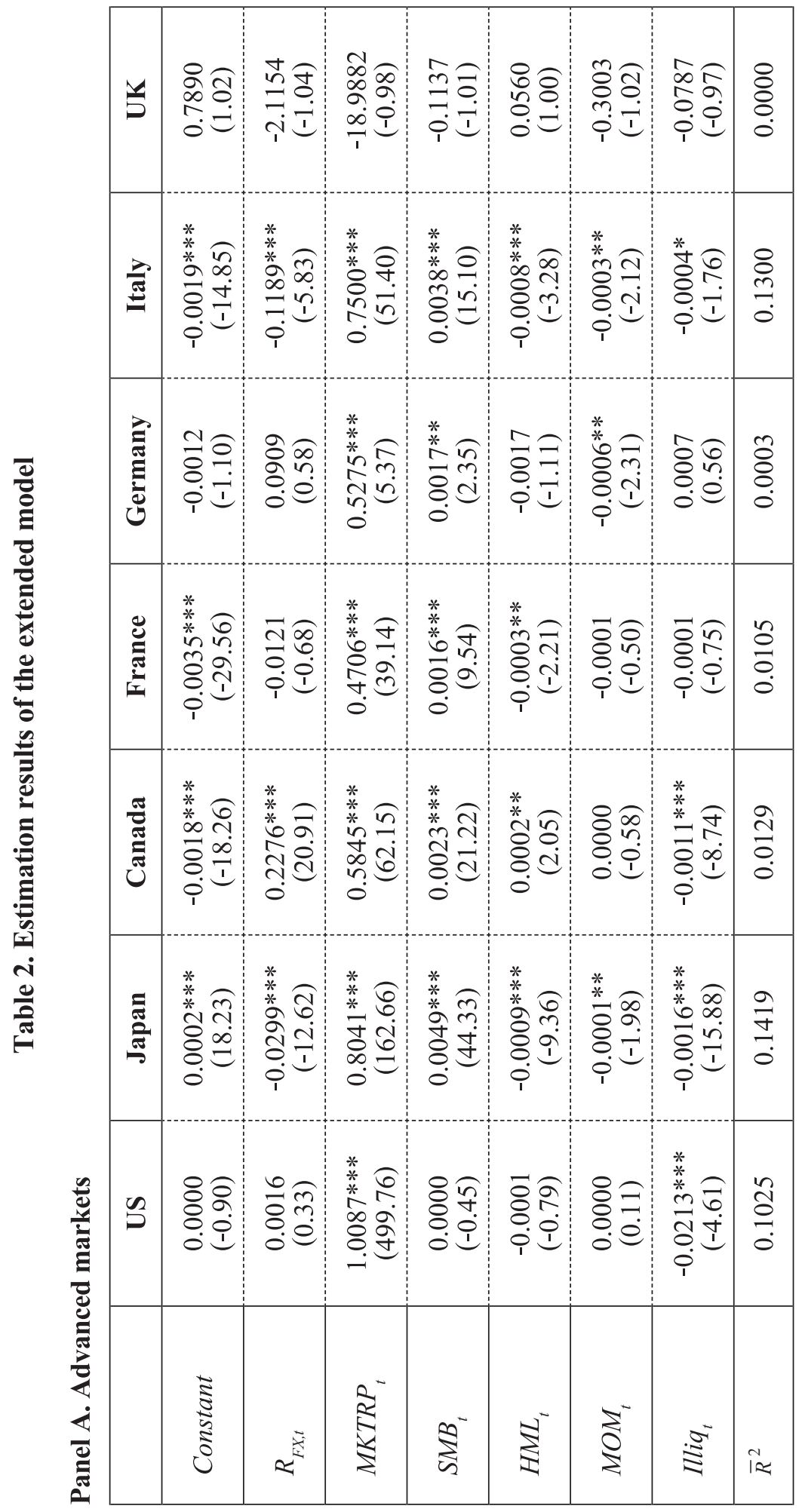




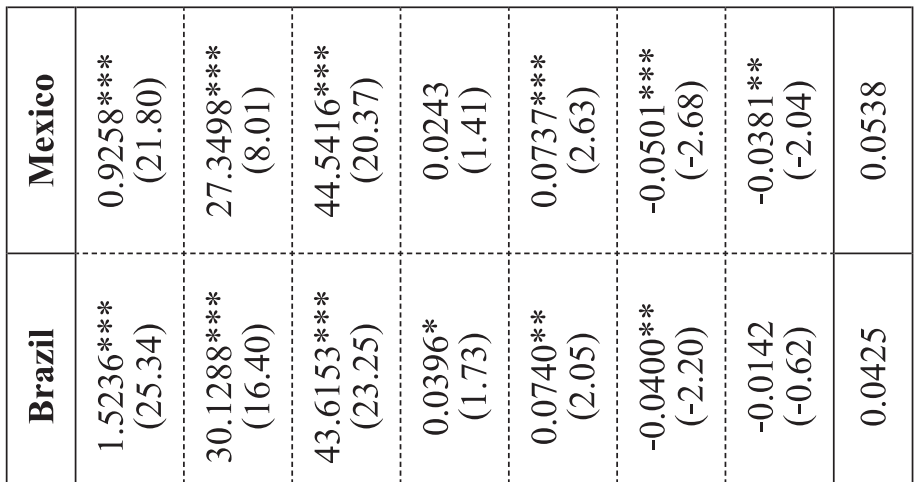

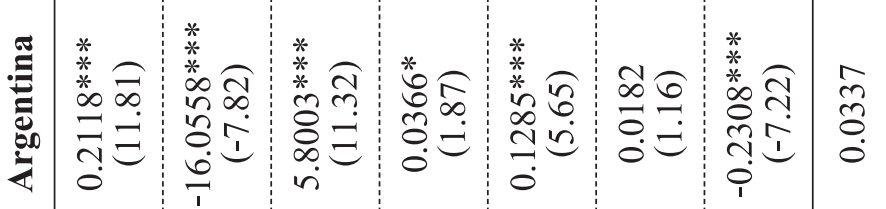

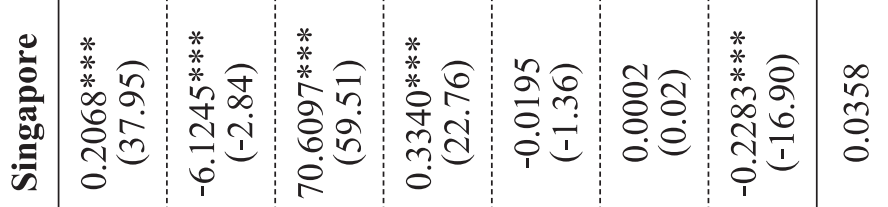

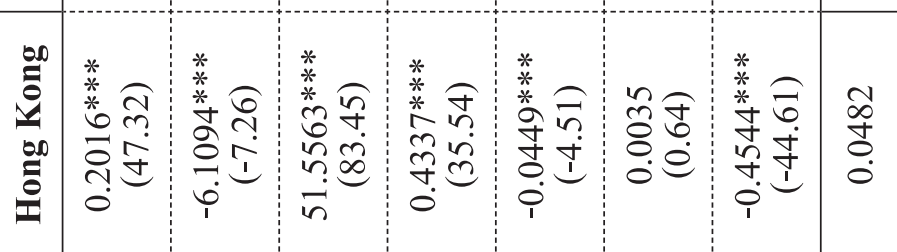

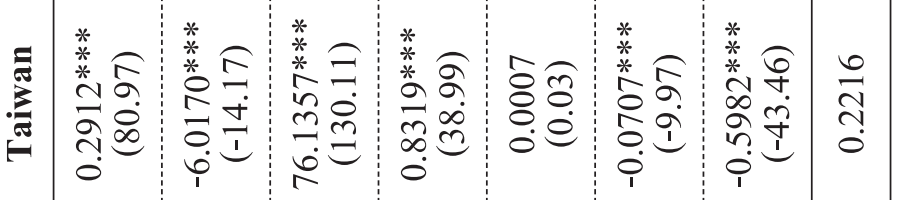

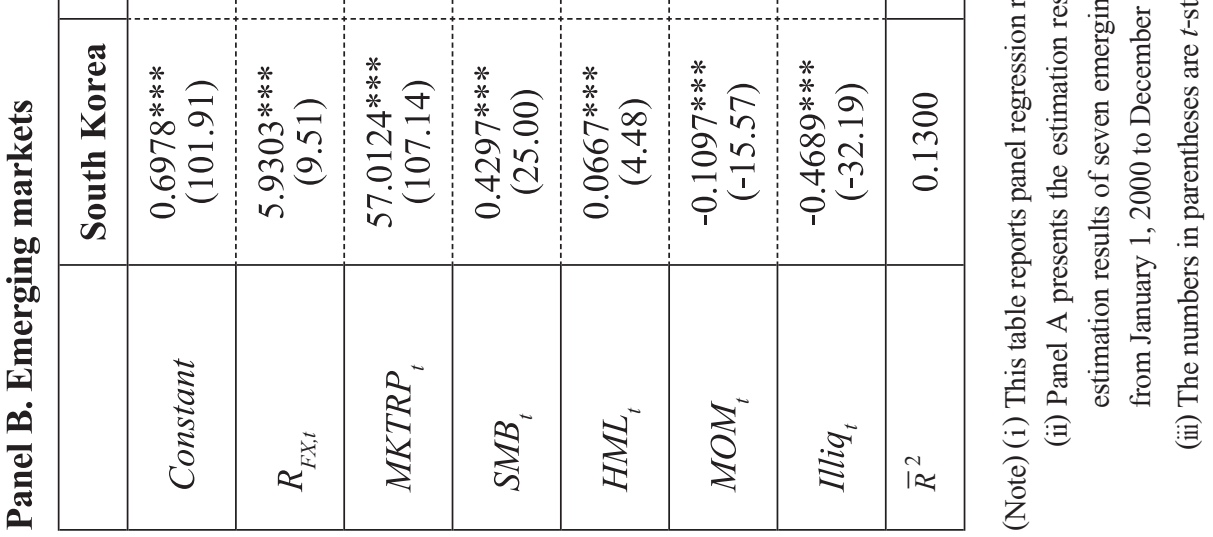


In summary, even with those important price factors, the level of statistical significance of changes in exchange rates on stock returns remains unaffected and is consistent with the baseline model. Exchange rate changes systematically affect stock prices of individual firms in all seven emerging economies as well as markets in Japan, Canada, and Italy.

\section{The extended model with international effects}

Since the US stock market is dominant in international markets (von Furstenberg and Jeon 1989, Griffin 2002, Connolly and Wang 2003, Chiang and Zheng 2010), we expect that variation in the US stock market spills over to stock markets in other countries. Therefore, we include the US market risk premium, $M K T R P_{U S}$, in the model and rewrite it as follows:

$$
\begin{aligned}
R_{i, t}-r_{f, t}=\beta_{0} & +\beta_{1} R_{F X, t}+\beta_{2} \text { MKTRP }_{t}+\beta_{3} M K T R P_{U S}+\gamma_{1} S M B_{t} \\
& +\gamma_{2} H M L_{t}+\gamma_{3} M O M_{t}+\gamma_{4} \text { Illiq }_{t}+\varepsilon_{i, t}
\end{aligned}
$$

where $M K T R P_{U S}$ denotes the US market risk premium, calculated as $R_{U S, m, t}-r_{U S, f, t}$. The other variables are the same as defined earlier in this paper.

Table 3 presents the estimation results. Overall, the results are still robust. The statistical significance of exchange rate exposure remains unchanged for most markets (except for Singapore, the coefficient becomes insignificant) after we incorporate the market risk premium of the US. The coefficients of the US market risk premium are statistically significant for all emerging markets and four advanced markets (excepting the UK and France), indicating that international influence is also important in explaining variations in excess stock returns and estimating exchange rate exposure in a global setting. Therefore, we adopt the enhanced model, Equation (6), for further sub-sample estimations and portfolio analysis. ${ }^{8}$

\footnotetext{
${ }^{8}$ We also include the lag and lead variables of exchange rate changes in the enhanced model. The estimation results are robust and the statistical significance of exchange rate risk remains unchanged.
} 


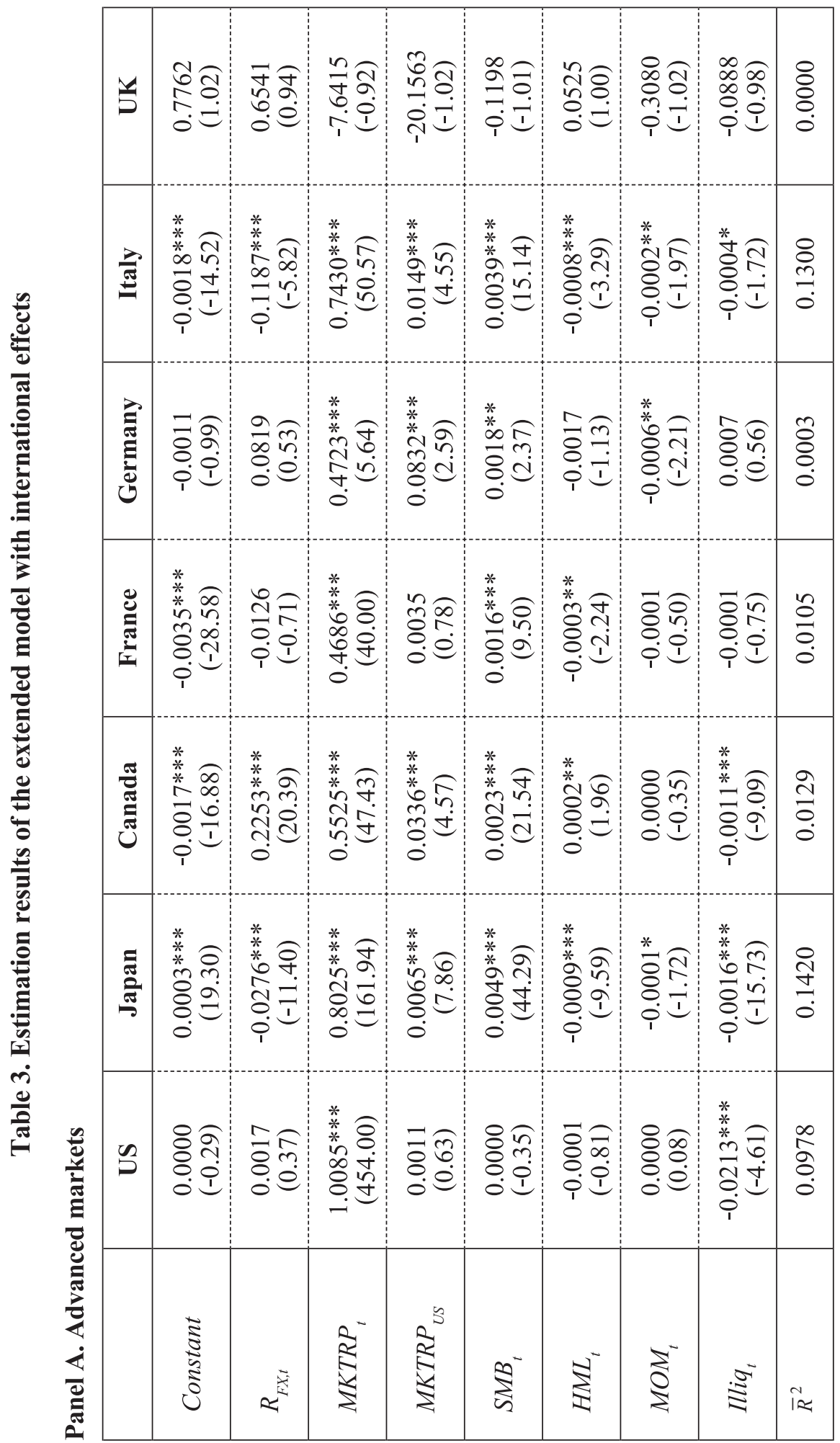




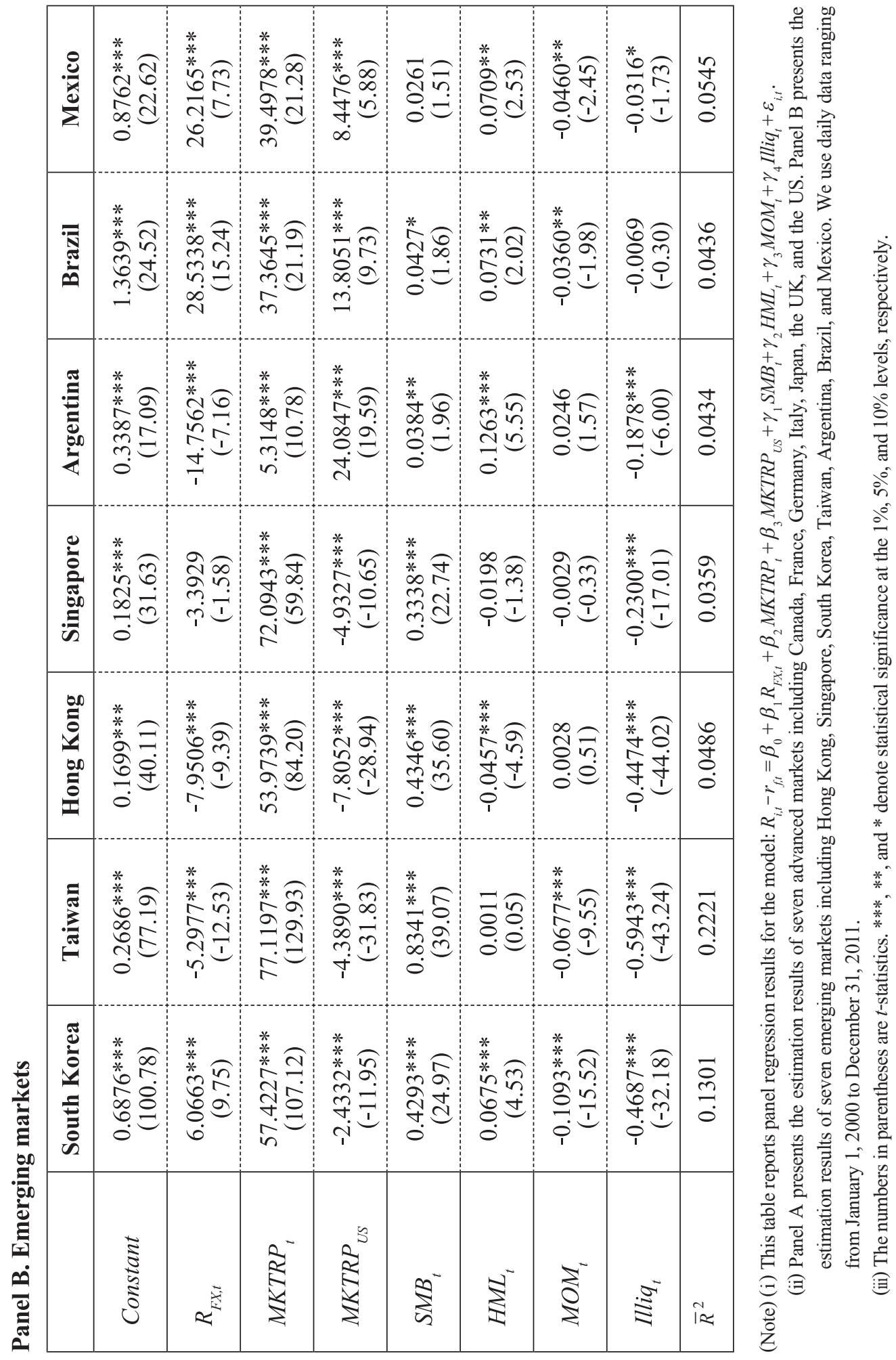




\section{B. Sub-sample estimations}

\section{Appreciation versus depreciation periods}

Our extended model estimation results reveal that the direction of exchange rate exposures varies across countries. For exporting firms, the depreciation of local currency promotes foreign sales, and therefore increases firms' value. On the other hand, the appreciation of local currency raises production costs and leads to lower stock returns. For importing firms, it works in the opposite manner. Distinguishing between appreciation and depreciation periods in the estimation can provide insights into the effect of exchange rate movements on stock returns.

We divide our sample into two groups. One group represents the periods of local currency appreciation. The other group represents the periods of local currency depreciation. We define positive changes in the local exchange rate index, $R_{F X, t}$, as local currency appreciation and negative changes as depreciation. The relationship between stock returns and the absolute value of currency changes is examined during appreciation periods and depreciation periods separately. Panel A of Table 4 compares the different exchange exposure effects between appreciation periods and depreciation periods in advanced markets, and Panel B compares them in emerging markets. 


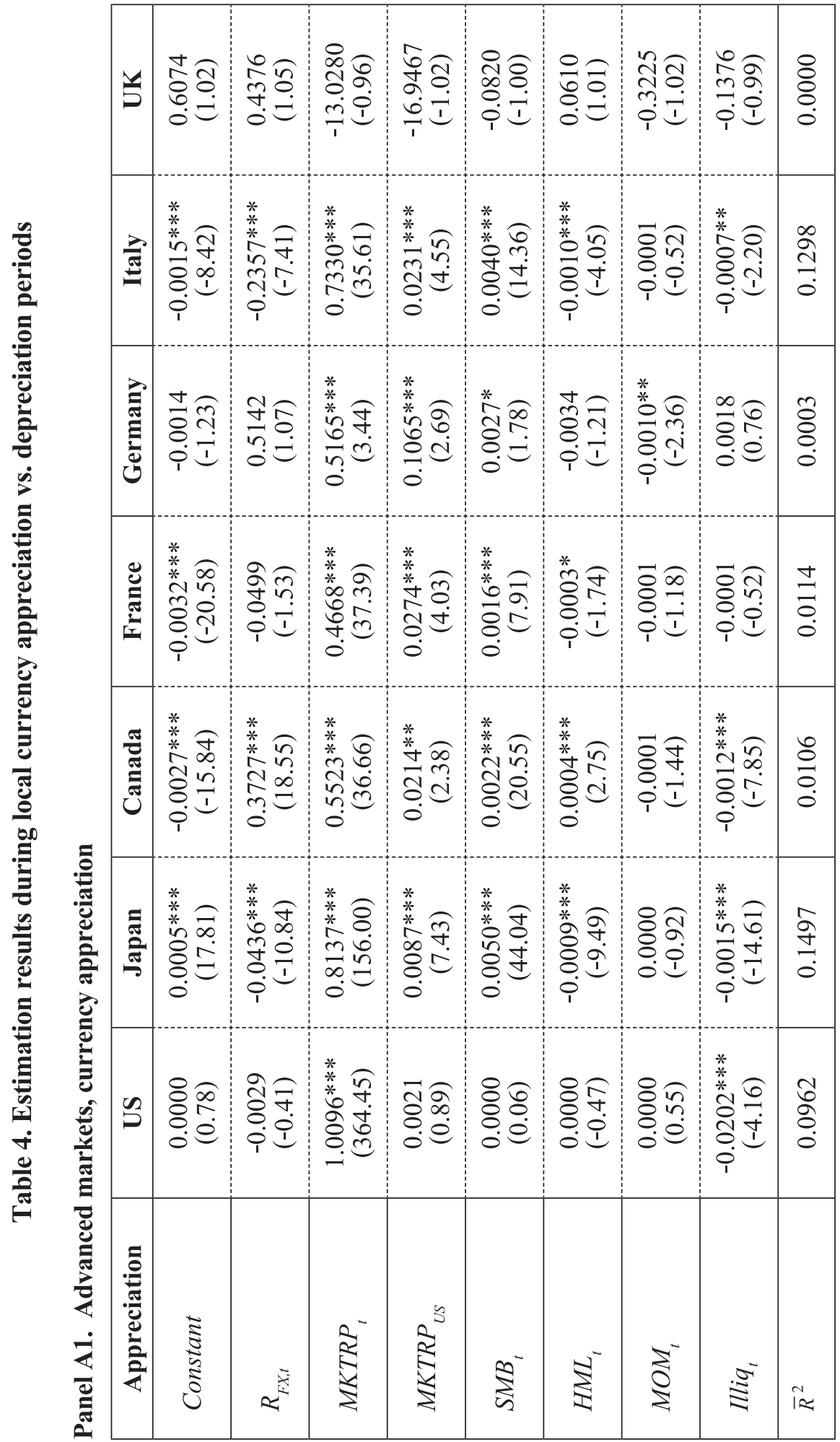




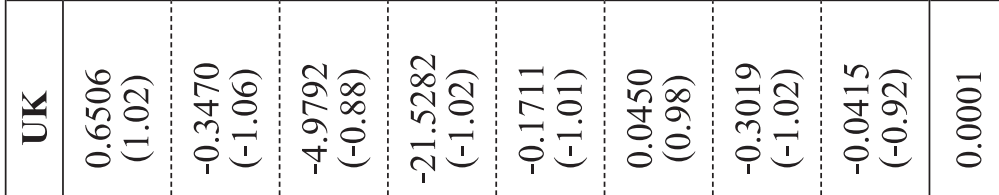

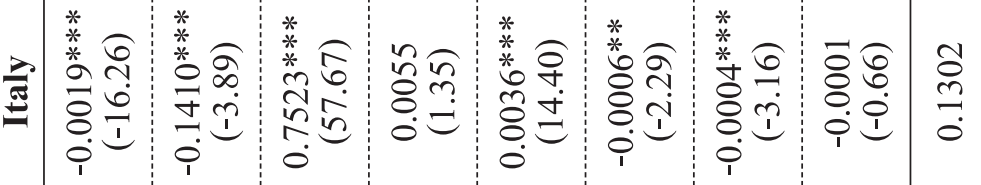

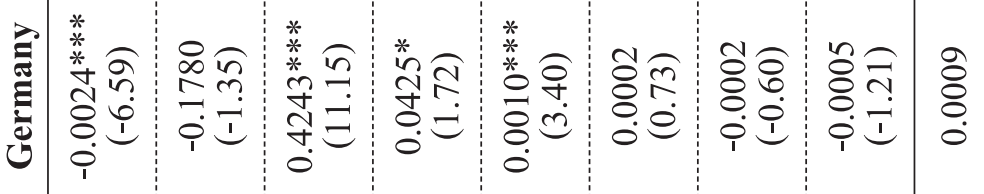

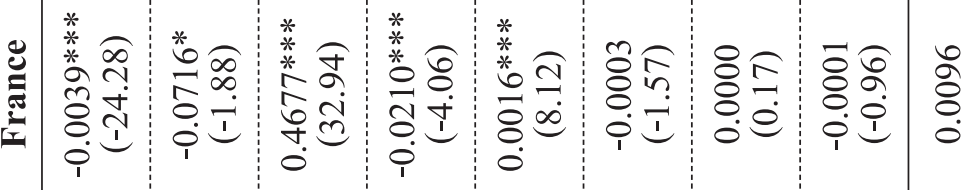

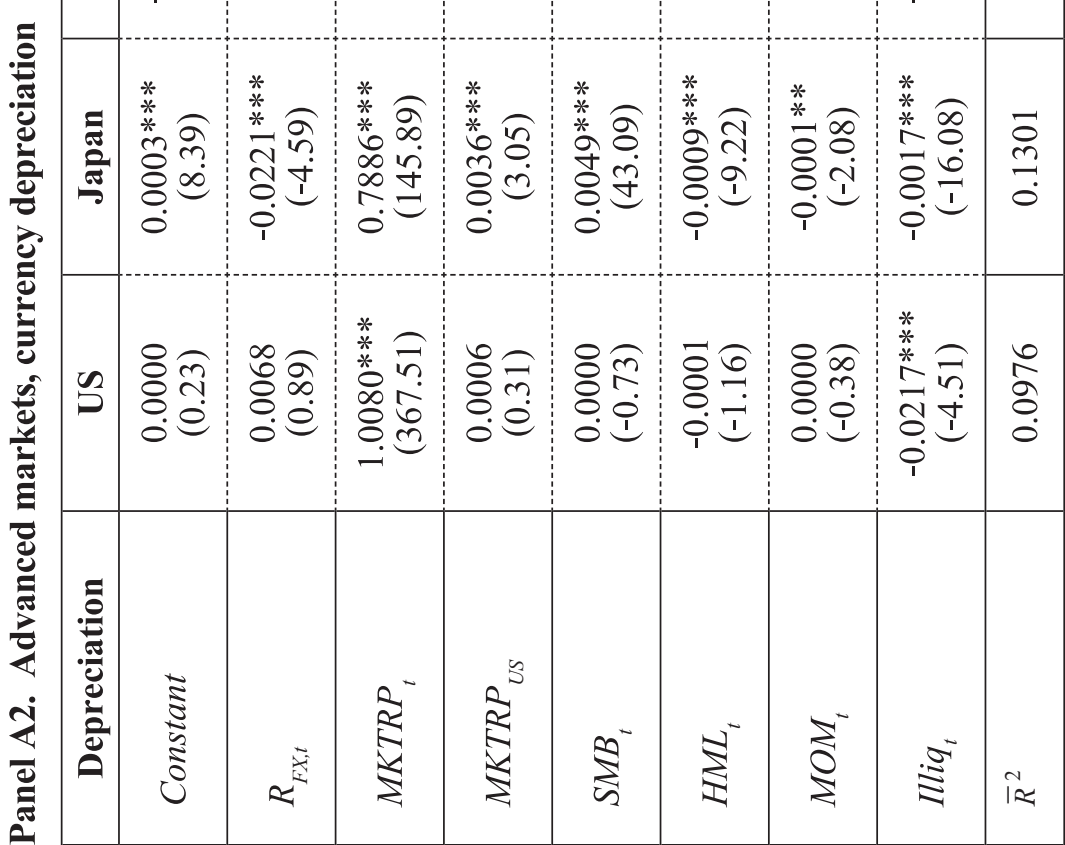




\begin{tabular}{|c|c|c|c|c|c|c|c|c|c|}
\hline & 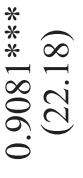 & 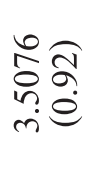 & 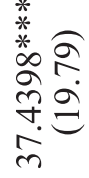 & 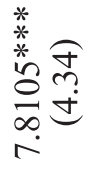 & 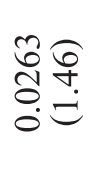 & 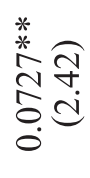 & 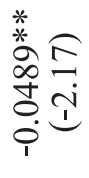 & 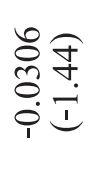 & $\begin{array}{l}\text { के } \\
\text { } \\
0 \\
0\end{array}$ \\
\hline & 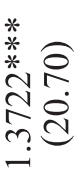 & 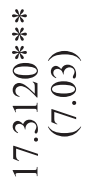 & 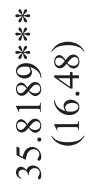 & 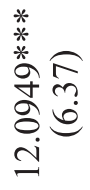 & $\begin{array}{l}80 \\
0 \\
0 \\
0 \\
0\end{array}$ & $\begin{array}{l}* \\
\infty \\
0 \\
0 \\
0 \\
0 \\
0\end{array}$ & 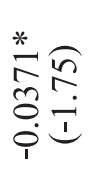 & 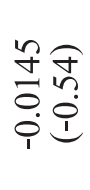 & 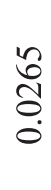 \\
\hline & 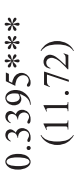 & 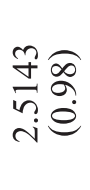 & 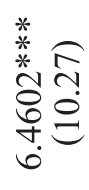 & 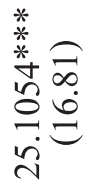 & $\begin{array}{l}\stackrel{+}{2} 0 \\
\text { ํㅡㄹ } \\
0\end{array}$ & 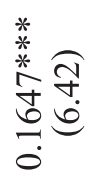 & 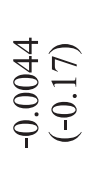 & 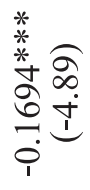 & $\begin{array}{l}\overline{6} \\
0 \\
0 \\
0\end{array}$ \\
\hline & 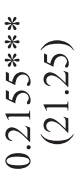 & 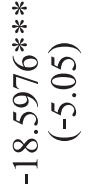 & 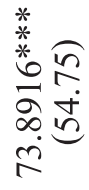 & 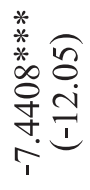 & 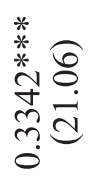 & 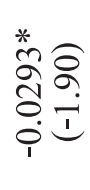 & 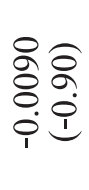 & 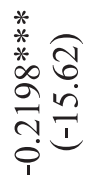 & 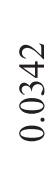 \\
\hline & 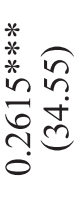 & 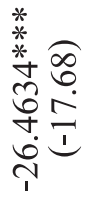 & 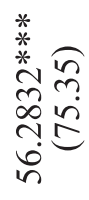 & 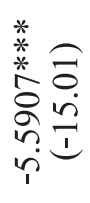 & 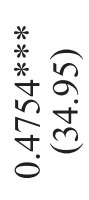 & 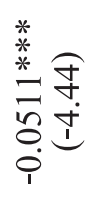 & 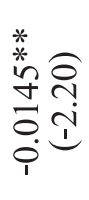 & 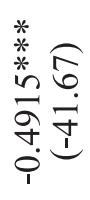 & 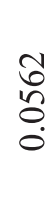 \\
\hline & 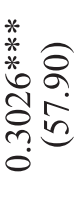 & 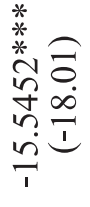 & 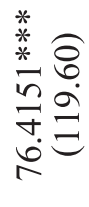 & 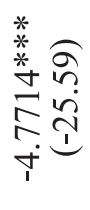 & 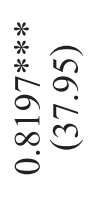 & $\begin{array}{l}m \widehat{n} \\
m 0 \\
0 \\
0 \\
i\end{array}$ & 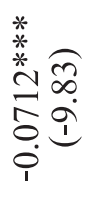 & 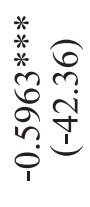 & 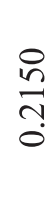 \\
\hline & 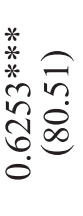 & \begin{tabular}{l}
$\hat{\sigma}$ \\
\multirow{T}{*}{$\underset{n}{n}$}
\end{tabular} & 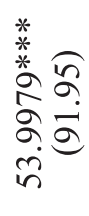 & 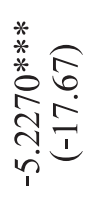 & 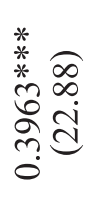 & 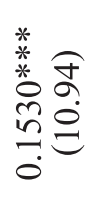 & 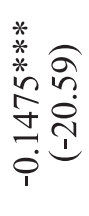 & 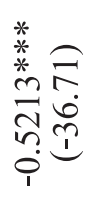 & $\begin{array}{l}\stackrel{0}{ } \\
\exists \\
0\end{array}$ \\
\hline$\frac{5}{2}$ & $\frac{\tilde{\Xi}}{\tilde{\Xi}}$ & $e^{x}$ & $\underset{z}{z}$ & $\begin{array}{l}\Sigma \\
z \\
z \\
z\end{array}$ & $\underset{\infty}{\infty}$ & $\underset{\Xi}{\exists}$ & 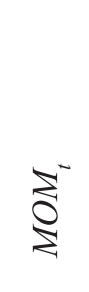 & $\stackrel{\Xi}{\Xi}$ & $\tilde{N}_{2}$ \\
\hline
\end{tabular}




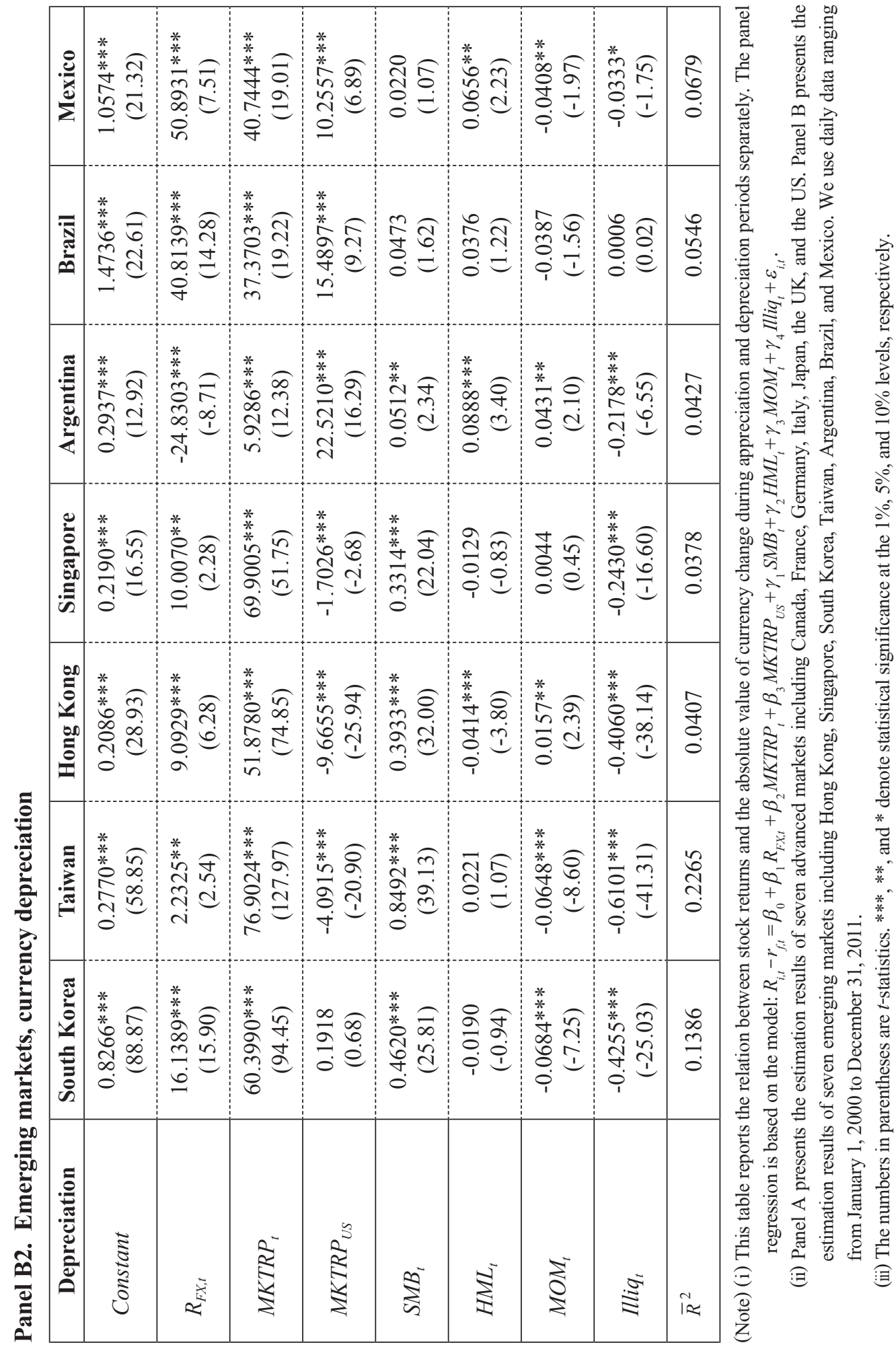


The direction of a consistent exposure is revealed in four Asian markets: South Korea, Taiwan, Hong Kong, and Singapore. The coefficient of the exchange rate change variable is significantly negative (excepting South Korea) during local currency appreciation periods and significantly positive during local currency depreciation periods. ${ }^{9}$ The magnitude of foreign exchange exposure is larger during the appreciation periods than that during the depreciation periods. The four Asian Tigers are well known for their successes in using export-led economic growth strategies. It supports the proposition that exports and foreign sales are key components of exchange rate exposures in these countries (Shapiro 1975, Levi 1994, Stone and Jeon 2000). ${ }^{10}$

In the three Latin American markets, Brazil and Mexico show a positive exposure to exchange rate fluctuations during both appreciation and depreciation periods, and the magnitude of the exposure is larger and more significant when exchange rates depreciate. The reversed signs, compared with the findings in Asian countries during currency appreciation periods, seem to be puzzling. It is worth noting that Brazil and Mexico are highly indebted emerging countries. The amounts of their external debt are among the top 10 in the world (World Bank 2013). It is likely that the appreciation of home currency generates a positive balance sheet effect and leads to an increase of the asset prices. A similar balance sheet effect of exchange rate changes has been reported in Brazil in the literature (Júnior 2011).

The advanced markets do not show strong consistency in terms of the direction of the exchange rate exposure. However, the magnitude of exchange rate exposure is larger when local currency appreciates for most G7 countries, excepting the US and France. It is possible that in the advanced economies, the exchange rate exposure effect of importoriented firms and export-oriented firms cancel each other out more than in emerging economies. As a result, the direction of net effects becomes ambiguous.

\section{Tranquil versus crisis periods}

Risk factors have been documented to have stronger effects during recession periods than non-recession periods (Lundblad 2007, Connolly et al. 2005). Therefore, it is important to investigate how exchange rate changes affect stock returns under different market conditions. We divide our sample into two sub-periods. Since early 2001, the

\footnotetext{
${ }^{9}$ This result is somewhat consistent with the finding by Bartram and Bodnar (2012) for emerging economies and Yang et al. (2014) for Asian countries.

${ }^{10}$ For various contributing factors for increasing volatility in Asian financial markets and macroeconomies, see Chiang et al. (2007), Kim and Jeon (2013) and Jeon and Wu (2014).
} 
Internet dot-com bubble crisis had been stabilized and the economy started to recover. We define the period July 1, 2001 to March 31, 2008, as the tranquil period. In mid-2008, the US government took control of Fannie Mae and Freddie Mac, which was followed by the collapse of Lehman Brothers. This signified the most recent global financial crisis. The crisis-induced recession technically ended in June 2009. Accordingly, we define the period April 1, 2008 to June 30, 2009, as the crisis period. Based on Equation (6), we run the regressions separately for the two sub-samples of the tranquil vs. the crisis periods.

Table 5 reports the estimation results. Panel A of Table 5 compares the difference in exchange rate exposure between the tranquil period and the crisis period for the advanced markets, and Panel B compares the difference between the two sub-periods for emerging markets. The absolute values of the coefficients on exchange rate changes are higher during the crisis period in five out of seven advanced markets (excepting Germany and the UK). More specifically, the coefficients change from significantly positive to significantly negative in France and Italy. A similar pattern is observed in emerging markets. The magnitude of exchange rate exposure is larger and more statistically significant in all four Asian markets during crisis periods. 


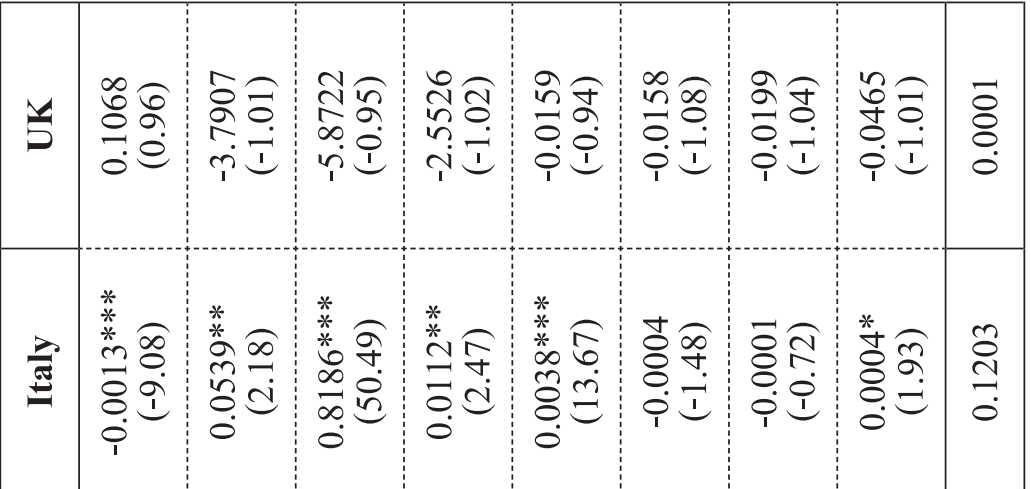

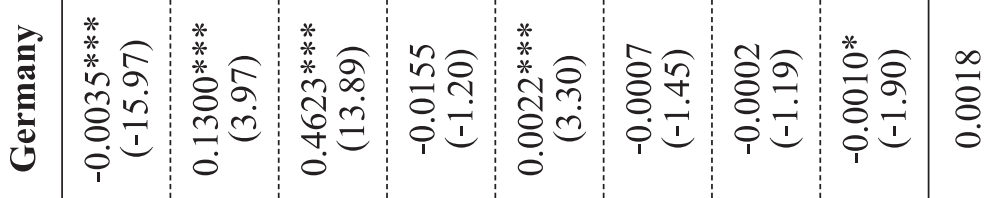

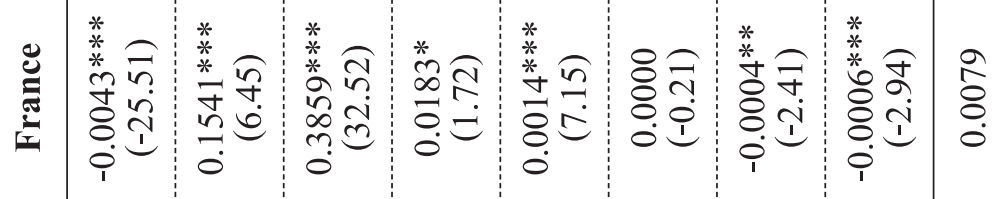

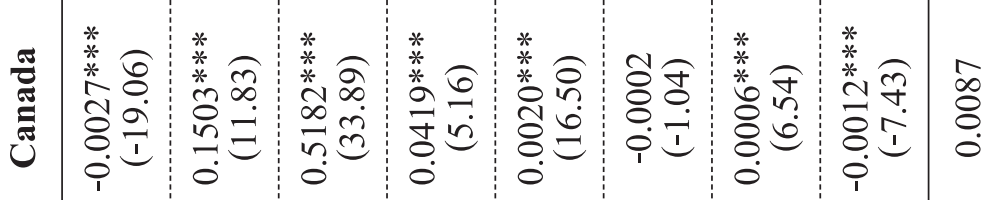

\begin{tabular}{|c|c|c|c|c|c|c|c|c|c|}
\hline 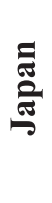 & 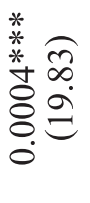 & 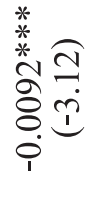 & 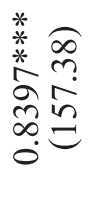 & 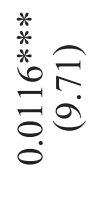 & 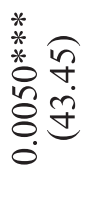 & 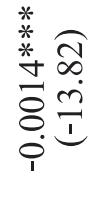 & 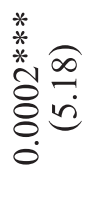 & 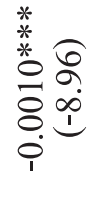 & $\stackrel{\frac{N}{m}}{\frac{m}{0}}$ \\
\hline $\mathscr{D}$ & $\begin{array}{l}8 \text { 종 } \\
8 \stackrel{0}{0} \\
01\end{array}$ & 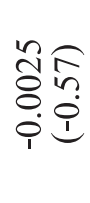 & 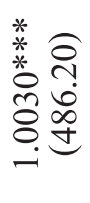 & $\begin{array}{l}\overline{0} \\
\overline{8} \\
\stackrel{0}{\circ}=\end{array}$ & 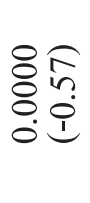 & 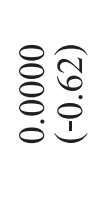 & 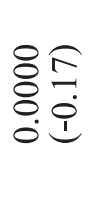 & 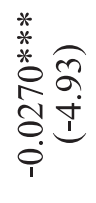 & $\begin{array}{l}\stackrel{2}{\circ} \\
\text { o. }\end{array}$ \\
\hline 急 & 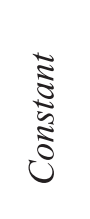 & $e^{x}$ & $\underset{z}{2}$ & $\frac{1}{2}$ & $\sum_{i}^{\infty}$ & $\bigotimes_{\beth}^{-}$ & 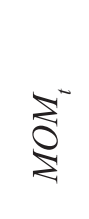 & $\stackrel{\Xi}{\Xi}$ & $R_{R}$ \\
\hline
\end{tabular}


อ

\begin{tabular}{|c|c|c|c|c|c|c|c|c|}
\hline 光 & 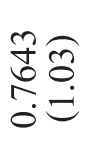 & 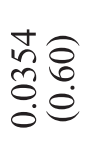 & 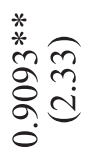 & 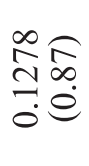 & 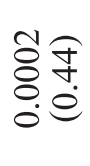 & 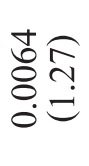 & 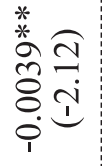 & 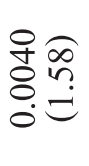 \\
\hline$\frac{\lambda}{\pi}$ & 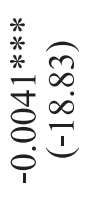 & 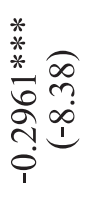 & 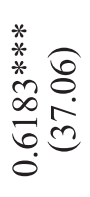 & $\begin{array}{l}80 \\
8: 0 \\
8= \\
0\end{array}$ & 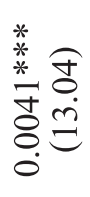 & 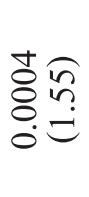 & 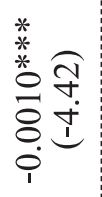 & 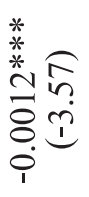 \\
\hline 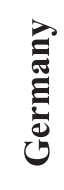 & 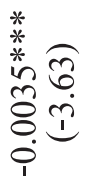 & 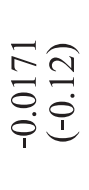 & 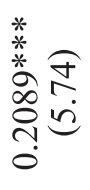 & 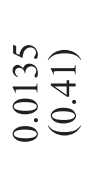 & $\begin{array}{l}\overrightarrow{8} \infty \\
\dot{8} \\
\dot{0}\end{array}$ & 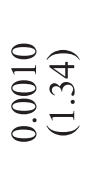 & 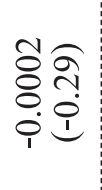 & 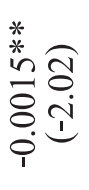 \\
\hline 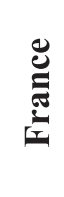 & 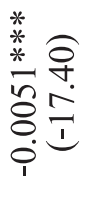 & 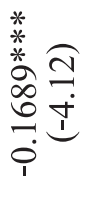 & 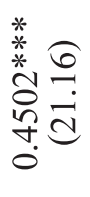 & 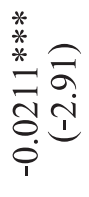 & 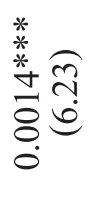 & 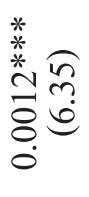 & 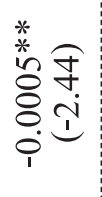 & $\begin{array}{l}\overrightarrow{8} \stackrel{\infty}{8} \\
\stackrel{0}{+} \\
\dot{0}\end{array}$ \\
\hline 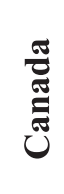 & 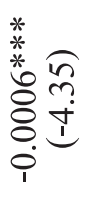 & 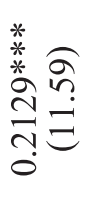 & 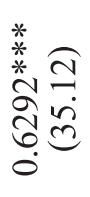 & 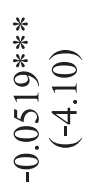 & 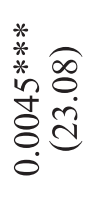 & 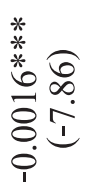 & 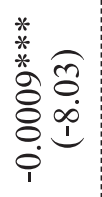 & 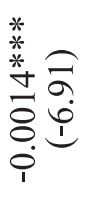 \\
\hline
\end{tabular}

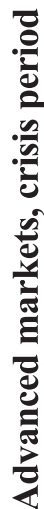

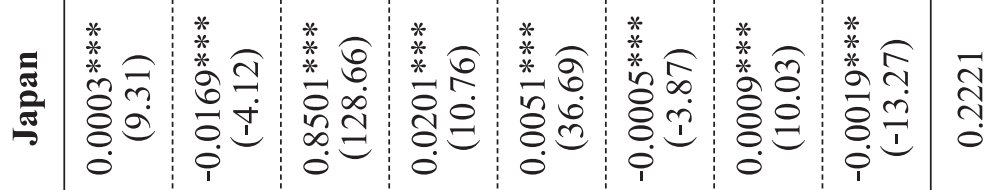

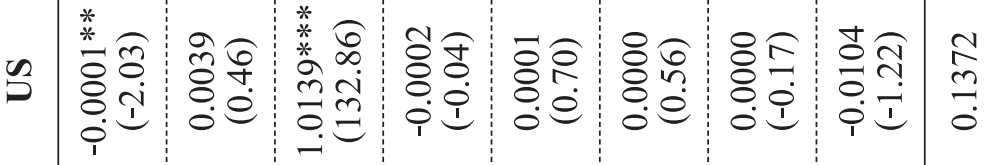




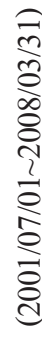

\begin{tabular}{|c|c|c|c|c|c|c|c|c|c|}
\hline$\frac{8}{\stackrel{e}{e}}$ & 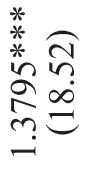 & 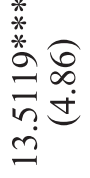 & 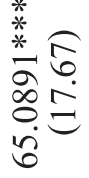 & 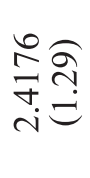 & 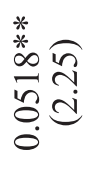 & \begin{tabular}{l}
$\vec{y}$ \\
$\stackrel{0}{0}$ \\
\hdashline
\end{tabular} & 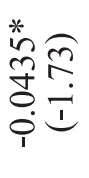 & 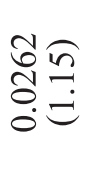 & $\begin{array}{l}\hat{6} \\
\dot{0} \\
0\end{array}$ \\
\hline דై & 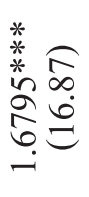 & 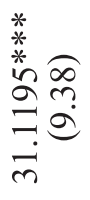 & 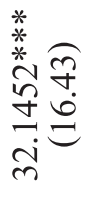 & 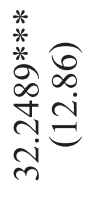 & 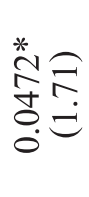 & $\begin{array}{l}\text { hôे } \\
\text { ț } \\
\stackrel{0}{0}=\end{array}$ & 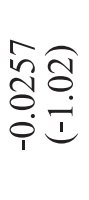 & 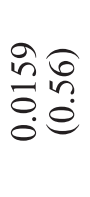 & 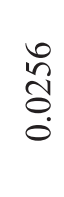 \\
\hline 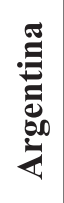 & 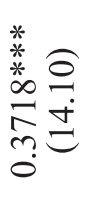 & 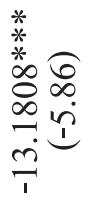 & 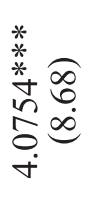 & 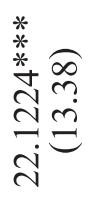 & 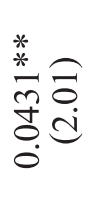 & 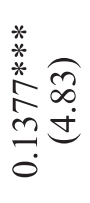 & 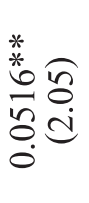 & 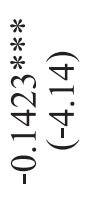 & 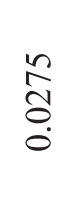 \\
\hline 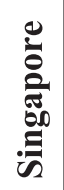 & 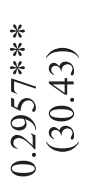 & $\begin{array}{l}\hat{m} \\
\hat{\sigma} \\
\dot{m}\end{array}$ & 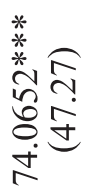 & $\begin{array}{l}* \\
* \\
* \\
\infty\end{array}$ & 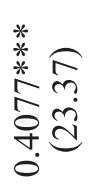 & 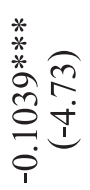 & 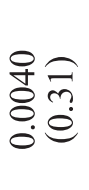 & 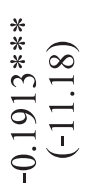 & $\begin{array}{l}\hat{0} \\
\text { to } \\
0 \\
0\end{array}$ \\
\hline 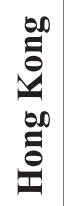 & 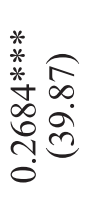 & 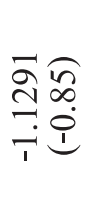 & 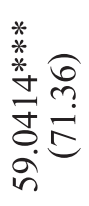 & 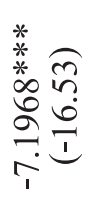 & 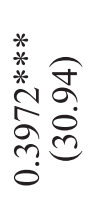 & 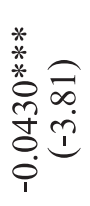 & 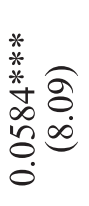 & 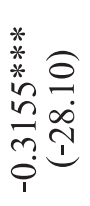 & $\begin{array}{l}\stackrel{1}{+} \\
\stackrel{0}{0} \\
0\end{array}$ \\
\hline 馬 & 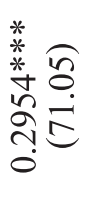 & 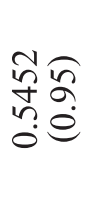 & 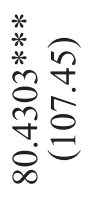 & 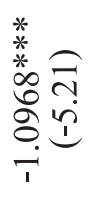 & 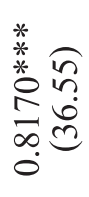 & 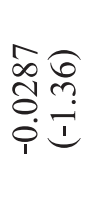 & 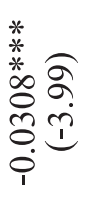 & 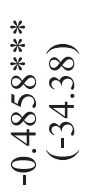 & $\begin{array}{l}\stackrel{a}{2} \\
\stackrel{0}{0}\end{array}$ \\
\hline 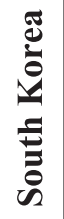 & 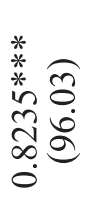 & 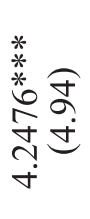 & 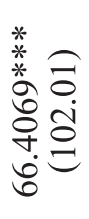 & 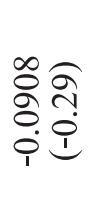 & 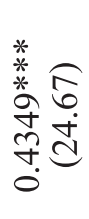 & $\begin{array}{l}\stackrel{*}{*} \\
\stackrel{*}{*} \underset{f}{\infty} \\
0 \\
0 \\
0 \\
0\end{array}$ & 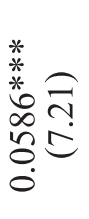 & 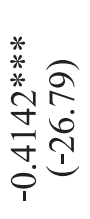 & 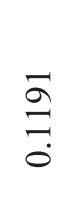 \\
\hline 茎 & 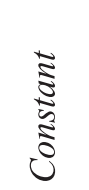 & 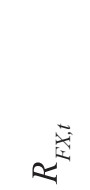 & $\underset{z}{z}$ & $\frac{3}{z}$ & $\underset{\leftarrow}{\infty}$ & $\underset{\searrow}{\searrow}$ & $\underset{\Sigma}{\Xi}$ & $\stackrel{\Xi}{\Xi}$ & Ix \\
\hline
\end{tabular}




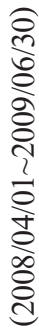

\begin{tabular}{|c|c|c|c|c|c|c|c|c|c|}
\hline 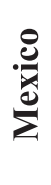 & 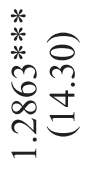 & 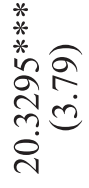 & 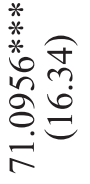 & 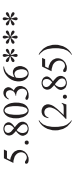 & 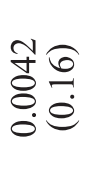 & 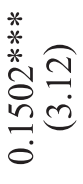 & 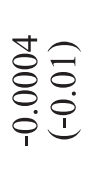 & 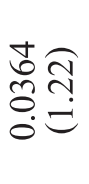 & $\stackrel{n}{\frac{n}{m}}$ \\
\hline 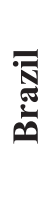 & 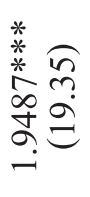 & 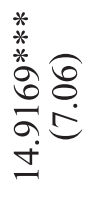 & 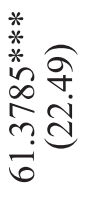 & 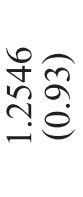 & 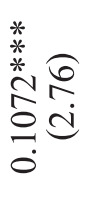 & 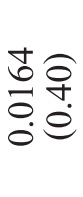 & 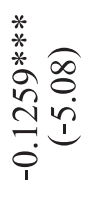 & 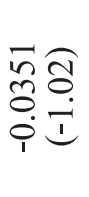 & $\frac{\mathcal{F}}{\Xi}$ \\
\hline & 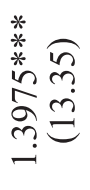 & 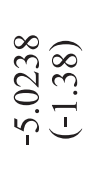 & 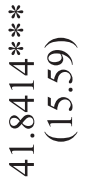 & 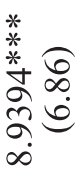 & 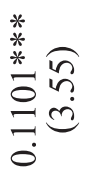 & 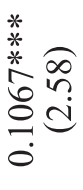 & 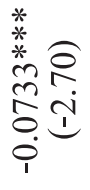 & 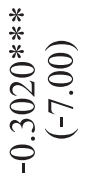 & $\begin{array}{l}0 \\
n \\
n \\
0\end{array}$ \\
\hline 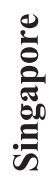 & 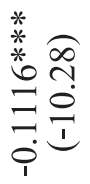 & 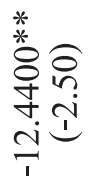 & 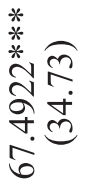 & 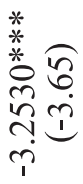 & 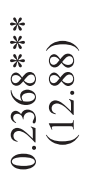 & 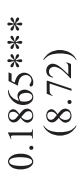 & 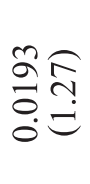 & 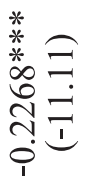 & $\begin{array}{l}\text { ڤे } \\
\text { है } \\
\dot{0}\end{array}$ \\
\hline
\end{tabular}

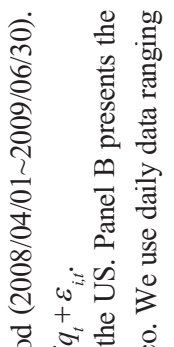

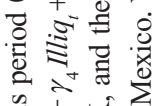

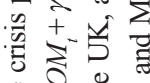

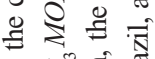

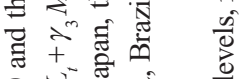

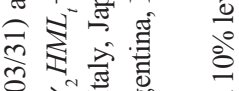

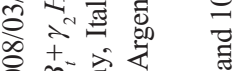

टे के है है की

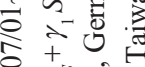

के

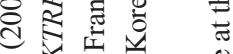

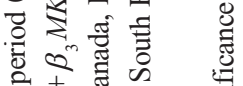

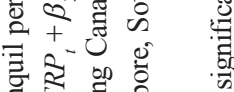

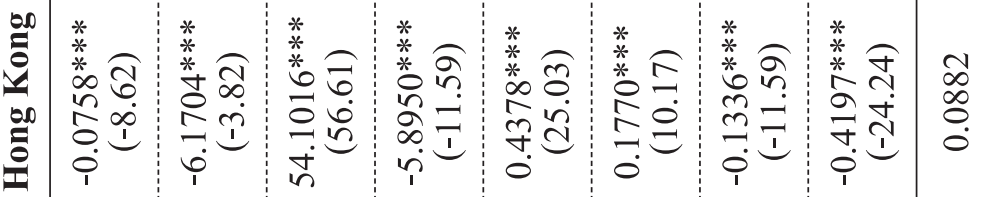

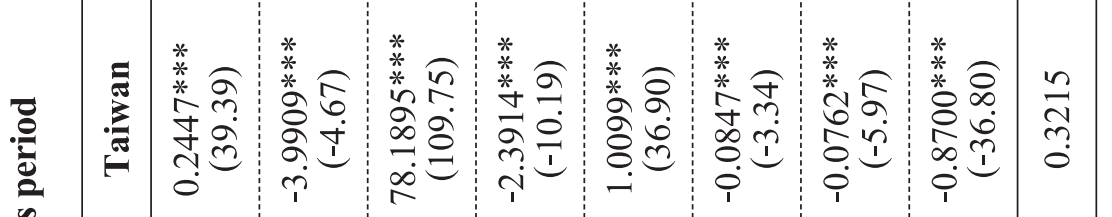

氜密

Ð

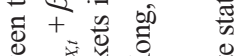

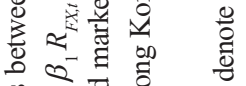

$\begin{array}{llll}0 & 0 & 0 & 0 \\ 0 & 0 & 0 \\ 0 & 0 & 0\end{array}$

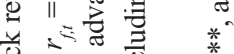

总 $=\overline{0}$.

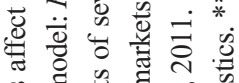

进苛言

एक

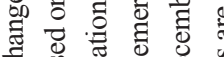

ชั

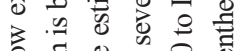

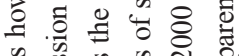

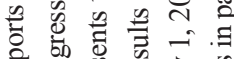

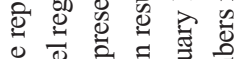

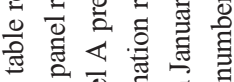

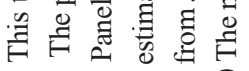

Ð 
Overall, exchange rate movements impact stock returns more significantly during crisis periods in most of the 14 markets. The incremental explanatory power of exchange rate changes on stock returns during crisis periods are also evidenced by increased $R^{2}$ values.

\section{Portfolio analysis}

This section presents portfolio analysis. First, we form portfolios by sorting firms with different market capitalizations and examine how exchange rate movements affect different size stock portfolios. Second, we conduct industry analysis to test the foreign exchange rate exposure effect in traded-goods and non-traded goods sectors.

\section{Market value-based portfolios}

Previous studies have documented an ambiguous relationship between currency risk and firm size. The supporting literature of a greater exchange rate exposure on larger firms argues that larger firms are more likely to be engaged in foreign trades and to have assets denominated in foreign currency. For example, $\mathrm{He}$ and $\mathrm{Ng}$ (1998) find a positive relationship between cash flow exposure and firm size in Japan. Some studies disagree with it. They suggest that given the large amount of foreign trades, larger firms are more likely to use foreign exchange hedging than smaller firms, so small firms are more likely to be exposed to exchange rate risk. In addition, small firms could also be affected by currency exposure because a greater proportion of their business would be affected when they engage in foreign trade.

In Table 6, we report the estimation results of the enhanced model, Equation (6), for the smallest-size stock portfolios and those for the largest-size stock portfolios. ${ }^{12}$ Stock portfolios are formed at every $20 \%$ scale according to the firms' market capitalization and are rebalanced every month. Accordingly, we define the lowest $20 \%$ group as the smallest stock portfolios and the highest $20 \%$ group as the largest stock portfolios.

\footnotetext{
${ }^{11}$ See, for example Starks and Wei (2005). Bartram et al. (2009) investigate firms' transactions of foreign exchange derivatives in 50 countries and suggest that firms are less likely to hedge in countries with less liquid derivative markets.

${ }^{12}$ Only the estimation results of the smallest and largest portfolios are presented in the table to save space.
} 
Table 6. Exchange rate exposure for market value-based portfolios

\section{Panel A. Advanced markets}

\begin{tabular}{|c|c|c|}
\hline \multirow{2}{*}{ Market } & \multicolumn{2}{|c|}{ Coefficients of $\boldsymbol{R}_{F X, t}$} \\
\hline & Small firms & Large firms \\
\hline US & $\begin{array}{l}0.0066 \\
(0.72)\end{array}$ & $\begin{array}{c}-0.0595 * * * \\
(-5.37)\end{array}$ \\
\hline Japan & $\begin{array}{c}-0.0359 * * * \\
(-5.45)\end{array}$ & $\begin{array}{c}-0.0194 * * * \\
(-3.41)\end{array}$ \\
\hline UK & $\begin{array}{c}4.6098 \\
(0.75)\end{array}$ & $\begin{array}{c}0.1023 * * * \\
(8.60)\end{array}$ \\
\hline Canada & $\begin{array}{c}0.1903 * * * \\
(5.25)\end{array}$ & $\begin{array}{c}0.1256^{* * *} \\
(8.79)\end{array}$ \\
\hline France & $\begin{array}{c}-0.0592 \\
(-0.93)\end{array}$ & $\begin{array}{c}0.0545^{*} \\
(1.80)\end{array}$ \\
\hline Germany & $\begin{array}{c}-0.3139 \\
(-1.36)\end{array}$ & $\begin{array}{c}0.2360 * * \\
(2.23)\end{array}$ \\
\hline Italy & $\begin{array}{c}-0.1867 * * * \\
(-3.56)\end{array}$ & $\begin{array}{c}-0.1472 * * * \\
(-2.89)\end{array}$ \\
\hline
\end{tabular}

Panel B. Emerging markets

\begin{tabular}{|c|c|c|}
\hline \multirow{2}{*}{ Market } & \multicolumn{2}{|c|}{ Coefficients of $\boldsymbol{R}_{F X, t}$} \\
\hline & Small firms & Large firms \\
\hline South Korea & $\begin{array}{c}4.8459 * * * \\
(3.60)\end{array}$ & $\begin{array}{c}4.8308^{* * * *} \\
(3.44)\end{array}$ \\
\hline Taiwan & $\begin{array}{c}-2.8577^{* *} \\
(-2.57)\end{array}$ & $\begin{array}{c}-2.8621^{* * *} \\
(-3.82)\end{array}$ \\
\hline Hong Kong & $\begin{array}{c}-11.9616^{* * *} \\
(-4.27)\end{array}$ & $\begin{array}{c}-11.5943^{* * *} \\
(-8.18)\end{array}$ \\
\hline Singapore & $\begin{array}{c}-0.1040 \\
(-0.01)\end{array}$ & $\begin{array}{c}-0.5837 \\
(-0.32)\end{array}$ \\
\hline Argentina & $\begin{array}{c}-17.8581^{* *} \\
(-1.98)\end{array}$ & $\begin{array}{c}-19.5028^{* * *} \\
(-6.26)\end{array}$ \\
\hline Brazil & $\begin{array}{c}19.8030^{* * *} \\
(3.86)\end{array}$ & $\begin{array}{c}24.5238 * * * \\
(9.19)\end{array}$ \\
\hline Mexico & $\begin{array}{c}22.4277^{* *} \\
(2.42)\end{array}$ & $\begin{array}{l}24.4805^{* * *} \\
(5.54)\end{array}$ \\
\hline
\end{tabular}

(Note) (i) This table reports the coefficients of the change in export-weighted exchange rates from regression results for five size-based portfolios. The estimated model is the extended model (Equation 6).

(ii) Stock portfolios are formed at every $20 \%$ scale according to firms' market capitalization and are rebalanced every month. (To save space, only the regression results of the smallest and the largest portfolios are presented in the table). Daily data ranges from January 1, 2000, to December 31, 2011.

(iii) The numbers in parentheses are $t$-statistics. $* * *, * *$, and $*$ denote statistical significance at the $1 \%, 5 \%$, and $10 \%$ levels, respectively. 
The results show that the values of both the smallest and largest firms are significantly affected by exchange rate changes in six emerging markets, excepting Singapore. It suggests that exchange rate movement systematically affects stock returns in emerging markets regardless of firms' size. The coefficients of the exchange rate changes are greater in absolute value for large firms in five out of seven emerging markets. Since larger firms are more likely to be international, exchange rate exposure affects them to a greater extent in emerging markets. Similar results are found by $\mathrm{He}$ and $\mathrm{Ng}$ (1998).

A different pattern is revealed in advanced markets. All the largest firms in the seven advanced countries are significantly exposed to foreign exchange fluctuations. The smallest firms are affected by exchange rate changes only in Japan, Canada, and Italy. However, the magnitude of exchange rate exposure is larger in the smallest firms. The finding that exchange rate exposure is greater in smaller-sized firms is consistent with the findings of Dominguea and Tesar (2006) and Doidge et al. (2006). Allayannis and Ofek (2001) argue that larger firms could have more and easier access to foreign exchange hedging to reduce currency risk.

Overall, our size-based portfolio analyses suggest that firms in emerging markets experience significant exchange rate exposure regardless of their sizes. The magnitude of exchange rate exposure is shown to be much larger for all sized firms in emerging markets than those in advanced markets. However, exchange rate movements affect larger firms in emerging markets but smaller firms in advanced markets to a larger extent.

\section{Industry-based portfolios}

Many studies have presented evidence that exchange rate exposure is larger for firms in traded-goods industries than those in non-traded goods industries in the US. However, several studies support alternative arguments. For example, Francis et al. (2008) investigate 36 US industries and find that manufacturing industries are more likely to be exposed to currency risk than other industries due to the large volume of foreign trade related to their manufactured goods and production inputs. However, they also argue that cross-border transportation costs are relatively high, so exchange rate changes could affect non-traded goods industries as well. Bodnar and Gentry (1993) also find that in the US, exchange rate fluctuations significantly affect several non-traded goods industries such as heavy construction, motor freight transportation, air transport, and business services industries. 
We distinguish traded-goods industries and non-traded goods industries following the definition adopted by Bodnar and Gentry (1993). The industry classification is derived according to DataStream Global Equity Index hierarchy based on Industry Classification Benchmark at the industry level 4, where the total market is divided into 41 sectors. Examples of traded-goods industries include automobiles and parts, food producers, electronic and electrical equipment, and oil products.

Table 7 reports regression results based on our extended model for traded-goods industries vs. non-traded goods industries. In the advanced markets, stock returns of firms in five out of seven economies are shown to be significantly affected by exchange rate changes in both traded and non-traded goods industries, including the US, the UK, Japan, Canada, and Italy. The exchange rate exposures are found to be statistically significant for six out of seven emerging markets in both traded and non-traded goods industries. Furthermore, the magnitude of the significant exchange rate exposure is higher in traded goods industries than that in non-traded goods industries, except Brazil and Mexico.

Table 7. Exchange rate exposure for industry-based portfolios

Panel A. Advanced markets

\begin{tabular}{|c|c|c|}
\hline \multirow{2}{*}{ Market } & \multicolumn{2}{|c|}{ Coefficients of $\boldsymbol{R}_{F X, t}$} \\
\cline { 2 - 3 } & Non-traded goods stocks & Traded goods stocks \\
\hline \multirow{2}{*}{ US } & $\begin{array}{c}0.0722^{* * *} \\
(4.97)\end{array}$ & $\begin{array}{c}-0.1163^{* * *} \\
(-5.18)\end{array}$ \\
\hline \multirow{2}{*}{ Japan } & $-0.0125^{* * *}$ & $-0.0463^{* * *}$ \\
& $(-3.68)$ & $(-13.48)$ \\
\hline \multirow{2}{*}{ UK } & $0.0446^{* * *}$ & $0.0649 * * *$ \\
& $(3.40)$ & $(7.01)$ \\
\hline \multirow{2}{*}{ Canada } & $0.1426^{* * *}$ & $0.2962 * * *$ \\
& $(10.44)$ & $(18.02)$ \\
\hline \multirow{2}{*}{ France } & -0.0127 & -0.0099 \\
& $(-0.53)$ & $(-0.37)$ \\
\hline \multirow{2}{*}{ Germany } & 0.1927 & -0.0518 \\
& $(0.72)$ & $(-0.73)$ \\
\hline \multirow{2}{*}{ Italy } & $-0.1119^{* * *}$ & $-0.1270 * * *$ \\
& $(-4.41)$ & $(-3.58)$ \\
\hline
\end{tabular}


Panel B. Emerging markets

\begin{tabular}{|c|c|c|}
\hline \multirow{2}{*}{ Market } & \multicolumn{2}{|c|}{ Coefficients of $\boldsymbol{R}_{F X, t}$} \\
\cline { 2 - 3 } & Non-traded goods stocks & Traded goods stocks \\
\hline \multirow{2}{*}{ South Korea } & $\begin{array}{c}5.9780^{* * *} \\
(5.45)\end{array}$ & $\begin{array}{c}7.6455^{* * *} \\
(9.53)\end{array}$ \\
\hline \multirow{2}{*}{ Taiwan } & $-7.1000^{* * *}$ & $-8.9973^{* * *}$ \\
& $(-5.14)$ & $(-7.90)$ \\
\hline \multirow{2}{*}{ Hong Kong } & $-2.9825^{* * *}$ & $-5.9470^{* * *}$ \\
& $(-3.77)$ & $(-11.72)$ \\
\hline \multirow{2}{*}{ Singapore } & -2.4977 & -4.2186 \\
& $(-0.77)$ & $(-1.34)$ \\
\hline \multirow{2}{*}{ Argentina } & $-8.3335^{* * *}$ & $-21.0907 * * *$ \\
& $(-3.69)$ & $(-6.61)$ \\
\hline \multirow{2}{*}{ Brazil } & $30.4236^{* * *}$ & $26.9699 * * *$ \\
& $(15.79)$ & $(6.47)$ \\
\hline \multirow{2}{*}{ Mexico } & $28.8439^{* * *}$ & $23.5683^{* * *}$ \\
& $(6.80)$ & $(3.57)$ \\
\hline
\end{tabular}

(Note) (i) This table reports the coefficients of the change in export-weighted exchange rates from the regression results for traded and non-traded industrial portfolios. The estimated model is the extended model (Equation 6).

(ii) The companies are divided into traded and non-traded industries following the definitions in the study by Bodnar and Gentry (1993). Industry classification follows DataStream Global Equity Index hierarchy based on ICB industry level 4. Daily data ranges from January 1, 2000, to December 31, 2011.

(iii) The numbers in parentheses are $t$-statistics. ***, **, and * denote the statistical significance at $1 \%, 5 \%$, and $10 \%$ levels, respectively.

The results support findings in the previous literature (Bartram and Karolyi 2006, Francis et al. 2008) that traded-goods industries are shown to be more vulnerable to exchange rate fluctuations than non-trade goods industries. Our findings have important implications from the international perspective. Our empirical study confirms that overall, the impact of exchange rate exposure is more concentrated in traded-goods industries than non-traded goods industries in both advanced and emerging markets. This relationship is more prevalent in emerging markets compared with the advanced economies. 


\section{Implications for economic integration}

Thus far, we have found that changes in exchange rates affect stock returns of individual firms at the high-frequency and firm levels for both advanced and emerging economies. We now proceed to examine if there are long-run equilibrium relationships between foreign exchange markets and stock markets across our sample countries at the national and aggregate levels. To this end, we collect national stock price indices and foreign exchange rate indices for the advanced and emerging economies matching our samples covered in this study. We conduct tests for long-run equilibrium relationships between the national stock markets and foreign exchange markets in the panel of our sample economies.

We apply panel cointegration analysis proposed by Pedroni (1999, 2004), which uses the panel $\rho$-statistic, panel $t$-statistic (panel PP), and panel parametric $t$-statistic (panel ADF) for within-group panel cointegration tests and the group $\rho$-statistic, nonparametric group $t$-statistic (group PP), and parametric group $t$-statistic (group ADF) for between-group cointegration tests. Table 8 reports the results of panel cointegration tests between national stock prices and nominal effective exchange rates in the panel of nine economies, which are confirmed to be nonstationary with panel unit roots for the advanced and emerging economies during the pre-crisis period and the post-crisis period. The results show that the null of no cointegration between stock prices and exchange rates in panels is accepted for the pre-crisis period, while it is rejected at least at the $10 \%$ significance level for the post-crisis period, based on the panel $\rho$-statistic and panel and group-mean PP and ADF test statistics.

\footnotetext{
${ }^{13}$ For stock prices, we obtain national stock price indices ( $Z F$ series), and for foreign exchange rates, we collect nominal effective exchange rates (NEER series) on a quarterly basis for nine advanced and emerging economies, namely, Canada, Japan, UK, US, the Euro area, South Korea, Singapore, Brazil and Mexico. The data source is International Financial Statistics from the IMF, and the data coverage period is from 2000Q1 to 2013Q3.
} 
Table 8. A long-run relationship between stock and exchange markets

\begin{tabular}{|l|c|c|c|c|}
\hline & \multicolumn{2}{|c|}{$\begin{array}{c}\text { The pre-crisis period } \\
(2000 \mathrm{Q} 1 \sim 2008 \mathrm{Q} 2)\end{array}$} & \multicolumn{2}{c|}{$\begin{array}{c}\text { The post-crisis period } \\
(2008 \mathrm{Q} 3 \sim 2013 \mathrm{Q} 3)\end{array}$} \\
\hline \multirow{2}{*}{ Test statistics } & $\begin{array}{c}\text { Within-group } \\
\text { (panel) }\end{array}$ & $\begin{array}{c}\text { Between-group } \\
\text { (group-mean) }\end{array}$ & $\begin{array}{c}\text { Within-group } \\
\text { (panel) }\end{array}$ & $\begin{array}{c}\text { Between-group } \\
\text { (group-mean) }\end{array}$ \\
\hline$\rho$-statistic & 0.848 & 2.565 & $2.790 * * *$ & $-1.325^{*}$ \\
& $(0.912)$ & $(0.995)$ & $(0.006)$ & $(0.093)$ \\
\hline$P P$-statistic & 0.336 & 2.508 & $-4.161 * * *$ & $-4.317 * * *$ \\
& $(0.917)$ & $(0.994)$ & $(0.0001)$ & $(0.000)$ \\
\hline$A D F$-statistic & -1.122 & 0.908 & $-1.601 * *$ & $-2.221 * *$ \\
& $(0.549)$ & $(0.818)$ & $(0.050)$ & $(0.013)$ \\
\hline
\end{tabular}

(Note) (i) This table reports the results of panel cointegration tests proposed by Pedroni $(1999,2004)$ using the panel $\rho$-statistic, panel parametric $t$-statistic (panel ADF), and panel $t$-statistic (panel PP) for withingroup panel cointegration tests and group $\rho$-statistic, non-parametric group $t$-statistic (group PP), and parametric group $t$-statistic (group ADF) for between-group cointegration test statistics. The numbers in parentheses are $p$ values. If the null hypothesis of no cointegration is rejected, there is evidence of the existence of panel cointegration between stock markets and foreign exchange markets across the sample economies.

(ii) For stock prices, we obtain national stock price indices ( $Z F$ series), and for foreign exchange rates, we collect nominal effective exchange rates (NEER series) for nine advanced and emerging economies on a quarterly basis, namely, Canada, Japan, UK, the US, and the Euro area, South Korea, Singapore, Brazil, and Mexico.

(iii) $* * *, * *$, and $*$ denote statistical significance at the $1 \%, 5 \%$, and $10 \%$ confidence level, respectively.

(Source) The data source is international financial statistics from the IMF, and the data coverage period is from 2000Q1 to 2013Q3.

The evidence for panel cointegration in the post-crisis period, but not in the pre-crisis period, implies that long-run exchange rate exposures have been strengthened in the panel of sample economies since the global financial crisis of 2007 2008. An increasing interconnectedness of global financial markets and economic integration across advanced and emerging economies are considered to be one of the major contributing factors to an increasing trend of long-run exchange rate exposures. 


\section{Conclusion}

In this study, we examine the impact of exchange rate changes on firms' stock returns in global markets. Using daily, international firm-level data from January 2000 to December 2011 in seven advanced markets (Canada, France, Germany, Italy, Japan, the UK, and the US) and seven emerging markets (Hong Kong, Singapore, South Korea, Taiwan, Argentina, Brazil, and Mexico), we present evidence of systematically significant exchange rate exposure for all seven emerging economies and three advanced markets. The main results remain robust in the extended exchange rate exposure model. We show consistent evidence that the extended model estimation corrects upward biased estimations of the baseline model. These findings are the main value-added contributions to the existing literature on the linkage between exchange rate changes and stock returns.

We further investigate exchange rate exposure under different market conditions. By comparing local currency appreciation periods and depreciation periods, we find that for export-orientated markets such as the four Asian Tigers, stock returns are positively and significantly correlated with exchange rate changes when currency depreciates while negatively correlated with exchange rate movements when currency appreciates. Additional results indicate that exchange rate exposure is more significant during crisis periods than tranquil periods in most of the 14 economies. Through portfolio analysis, we find that changes in exchange rate affect larger firms (with more intense global connections) in emerging markets, but smaller firms (with limited access to hedging) in advanced markets to a larger extent. The results also reveal that exchange rate exposure is more likely to influence stock returns of traded-goods industries than those of nontraded goods industries in both advanced and emerging markets, although the impact is more significant in emerging markets. In addition, we present evidence of long-run equilibrium relations between stock markets and foreign exchange markets after the global financial crisis of 2008 2009, implying an increasing trend of exchange rate exposures and economic integration in the global economy.

This study sheds light on how exchange rate movements systematically affect firmlevel stock returns in international markets in a high-frequency data context. Future studies could further explore the impact of exchange rate fluctuation on returns in different categories of stocks, applying dynamic analyses that include lead and lag effects and causality testing. It will also be interesting to examine how trade patterns within the same industry and/or across different countries could explain the varying role 
of exchange rate exposure in determining firm-specific stock returns. The findings will help to derive useful implications for exchange risk hedging strategies as well as policies for economic integration in the global economy.

Received 11 October 2016, Revised 16 January 2017, Accepted 24 January 2017

\section{References}

Acharya, Viral V., and Lasse Heje Pedersen. "Asset Pricing with Liquidity Risk." Journal of Financial Economics 77, no. 2 (2005): 375-410.

Adler, Michael, and Bernard Dumas. "Exposure to Currency Risk: Definition and Measurement." Financial Management (1984): 41-50.

Allayannis, George, and Eli Ofek. "Exchange Rate Exposure, Hedging, and the Use of Foreign Currency Derivatives." Journal of International Money and Finance 20, no. 2 (2001): 273-296.

Amihud, Yakov. "Exchange Rates and the Valuation of Equity Shares." In Exchange Rates and Corporate Performance, edited by Yakov Amihud and Richard M. Levich, 49-59. New York, 1994.

Amihud, Yakov. "Illiquidity and Stock Returns: Cross-section and Time-series Effects." Journal of Financial Markets 5, no. 1 (2002): 31-56.

Bartram, Söhnke M. "Linear and Nonlinear Foreign Exchange Rate Exposures of German Nonfinancial Corporations." Journal of International Money and Finance 23, no. 4 (2004): 673-699.

Bartram, Söhnke M., and Gordon M. Bodnar. "The Exchange Rate Exposure Puzzle." Managerial Finance 33, no. 9 (2007): 642-666.

Bartram, Söhnke M., and Gordon M. Bodnar. "Crossing the Lines: The Conditional Relation between Exchange Rate Exposure and Stock Returns in Emerging and Developed Markets." Journal of International Money and Finance 31, no. 4 (2012): 766792. 
Bartram, Söhnke M., Gregory W. Brown, and Frank R. Fehle. "International Evidence on Financial Derivatives Usage." Financial Management 38, no. 1 (2009): 185-206.

Bartram, Söhnke M., and G. Andrew Karolyi. "The Impact of the Introduction of the Euro on Foreign Exchange Rate Risk Exposures." Journal of Empirical Finance 13, no. 4 (2006): 519-549.

Bodnar, Gordon M., and William M. Gentry. "Exchange Rate Exposure and Industry Characteristics: Evidence from Canada, Japan, and the USA." Journal of International Money and Finance 12, no. 1 (1993): 29-45.

Carhart, Mark M. "On persistence in Mutual Fund Performance." The Journal of Finance 52, no. 1 (1997): 57-82.

Chiang, Thomas C., Bang Nam Jeon, and Huimin Li. "Dynamic Correlation Analysis of Financial Contagion: Evidence from Asian Markets." Journal of International Money and Finance, 26, no. 7 (2007): 1206-1228.

Chiang, Thomas C., and Dazhi Zheng. "An Empirical Analysis of Herd behavior in Global Stock Markets." Journal of Banking \& Finance 34, no. 8 (2010): 1911-1921.

Choi, Jongmoo Jay, and Anita Mehra Prasad. "Exchange Risk Sensitivity and Its Determinants: A Firm and Industry Analysis of US Multinationals." Financial Management (1995): 77-88.

Connolly, Robert A., and F. Albert Wang. "International Equity Market Comovements: Economic Fundamentals or Contagion?" Pacific-Basin Finance Journal 11, no. 1 (2003): 23-43.

Connolly, Robert, Chris Stivers, and Licheng Sun. "Stock Market Uncertainty and the Stock-bond Return Relation." Journal of Financial and Quantitative Analysis 40, no. 01 (2005): 161-194.

Doidge, Craig, John Griffin, and Rohan Williamson. "Measuring the Economic Importance of Exchange Rate Exposure." Journal of Empirical Finance 13, no. 4 (2006): 550-576.

Dominguez, Kathryn M.E. and Linda L. Tesar "A Reexamination of Exchange-rate Exposure.” American Economic Review 91, no. 2 (2001a): 396-399.

Dominguez, Kathryn M.E. and Linda L. Tesar "Trade and Exposure." American 
Economic Review 91, no. 2 (2001b): 367-370.

Dominguez, Kathryn M.E., and Linda L. Tesar. "Exchange Rate Exposure." Journal of International Economics 68, no. 1 (2006): 188-218.

Fama, Eugene F., and Kenneth R. French. "Common Risk Factors in the Returns on Stocks and Bonds." Journal of Financial Economics 33, no. 1 (1993): 3-56.

Francis, Bill B., Iftekhar Hasan, and Delroy M. Hunter. "Can Hedging Tell the Full Story? Reconciling Differences in United States Aggregate-and Industry-level Exchange Rate Risk Premium." Journal of Financial Economics 90, no. 2 (2008): 169-196.

Griffin, John M., and René M. Stulz. "International Competition and Exchange Rate Shocks: A Cross-Country Industry Analysis of Stock Returns." Review of Financial Studies 14, no. 1 (2001): 215-241.

Griffin, John M. "Are the Fama and French Factors Global or Country Specific?" Review of Financial Studies 15, no. 3 (2002): 783-803.

He, Jia, and Lilian K. Ng. "The Foreign Exchange Exposure of Japanese Multinational Corporations." The Journal of Finance 53, no. 2 (1998): 733-753.

Jeon, Bang Nam. "From the 1997-8 Asian Financial Crisis to the 2008-9 Global Economic Crisis: Lessons from Korea's Experience." East Asia Law Review (Penn Law School) 5, no. 1 (2010): 103-155.

Jeon, Bang Nam, and Ji Wu. "The Role of Foreign Banks in Monetary Policy Transmission: Evidence from Asia during the Crisis of 2008-9." Pacific-Basin Finance Journal 29 (2014): 96-120.

Kim, Won Y. and Bang Nam Jeon. "Has International Capital Mobility Increased in Asia? Evidence from the Post-1997 Financial Crisis Period." Contemporary Economic Policy 31, no. 2 (2013): 345-365.

Jorion, Philippe. "The Exchange-rate Exposure of US Multinationals." Journal of Business 63, no. 3 (1990): 331-345.

Júnior, José Luiz Rossi. "Exchange Rate Exposure, Foreign Currency Debt, and the Use of Derivatives: Evidence from Brazil." Emerging Markets Finance and Trade 47, no. 1 (2011): 67-89.

Leahy, Michael P. "New Summary Measures of the Foreign Exchange Value of the 
Dollar." Federal Reserve Bulletin 84 (1998): 811-818.

Levi, Maurice D. "Exchange Rates and the Valuation of Firms." In Exchange Rates and Corporate Performance, edited by Yakov Amihud and Richard M. Levich, 37-48. New York: Irwin, 1994.

Lundblad, Christian. "The Risk Return Tradeoff in the Long Run: 1836-2003." Journal of Financial Economics 85, no. 1 (2007): 123-150.

Miles, David, and Allan Timmermann. "Variation in Expected Stock Returns: Evidence on the Pricing of Equities from a Cross-section of UK Companies." Economica 63 (1996): 369-382.

Moore, Tomoe, and Ping Wang. "Dynamic Linkages between Real Exchange Rates and Stock Prices: Evidence from Developed and Emerging Asian Markets." International Review of Economics and Finance 29 (2014): 1-11.

Pantzalis, Christos, Betty J. Simkins, and Paul A. Laux. "Operational Hedges and the Foreign Exchange Exposure of US Multinational Corporations." Journal of International Business Studies 32, no. 4 (2001): 793-812.

Pástor, ubo, and Robert F. Stambaugh. "Liquidity Risk and Expected Stock Returns." Journal of Political Economy 111, no. 3 (2003): 642-685.

Pedroni, Peter. "Critical Values for Cointegration Tests in Heterogeneous Panels with Multiple Regressors." Oxford Bulletin of Economics and Statistics 61, no. s1 (1999): 653-670.

Pedroni, Peter. "Panel Cointegration: Asymptotic and Finite Sample Properties of Pooled Time Series Tests with an Application to the PPP Hypothesis." Econometric Theory 20, no. 03 (2004): 597-625.

Shapiro, Alan C. "Exchange Rate Changes, Inflation, and the Value of the Multinational Corporation." The Journal of Finance 30, no. 2 (1975): 485-502.

Starks, Laura T., and Kelsey D. Wei. "Foreign Exchange Exposure and Short-term Cash Flow Sensitivity." Working paper, University of Texas, Austin, 2003.

Stone, Susan F., and Bang Nam Jeon. "Foreign Direct Investment and Trade in the Asia-Pacific Region: Complementarity, Distance and Regional Economic Integration." Journal of Economic Integration 15 (2000): 460-485. 
von Furstenberg, George M., Bang Nam Jeon. "International Stock Price Movements: Links and Messages." Brookings Papers on Economic Activity 1989, no. 1 (1989): 125179 .

World Bank. International Debt Statistics 2013. Washington, DC: World Bank, 2013.

Yang, Zheng, Anthony H. Tu, and Yong Zeng. "Dynamic Linkages between Asian Stock Prices and Exchange Rates: New Evidence from Causality in Quantiles." Applied Economics 46, no. 11 (2014): 1184-1201. 


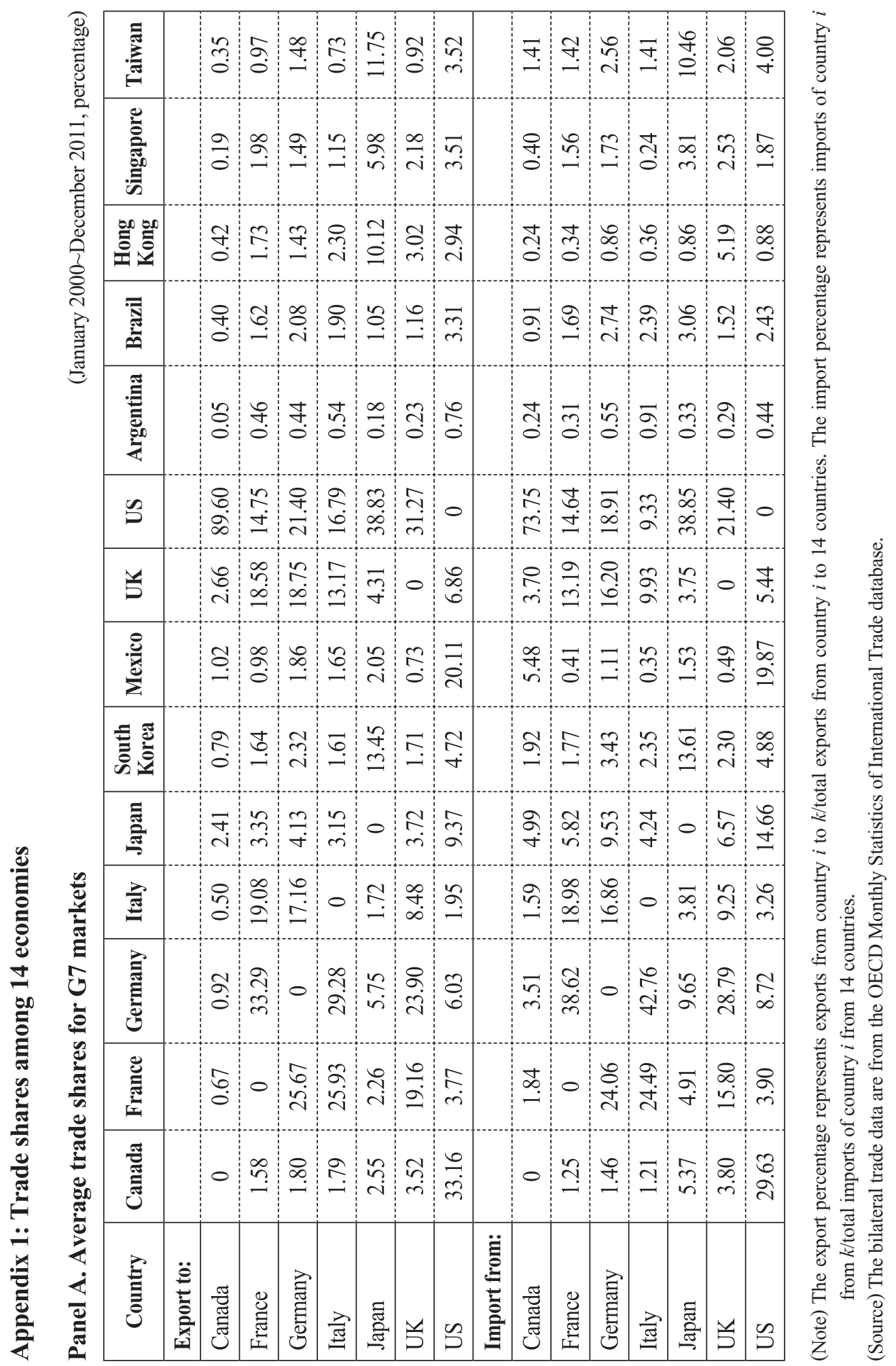




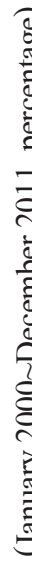

\begin{tabular}{|c|c|c|c|c|c|c|c|c|c|c|c|c|c|c|c|c|}
\hline 离 & & $\stackrel{m}{r}$ & 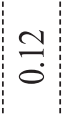 & & & & & & & $\begin{array}{l}\infty \\
0 \\
0\end{array}$ & ñ & & & & & \\
\hline 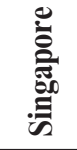 & & $\vec{\infty}$ & $\frac{I}{0}$ & & & & & & & $\begin{array}{l}\sigma \\
+\end{array}$ & $\begin{array}{l}\infty \\
0\end{array}$ & & & & & \\
\hline $\begin{array}{l}000 \\
00 \\
0 \\
0\end{array}$ & & $\stackrel{ }{\stackrel{2}{c}}$ & $\frac{m}{\circ}$ & & & & & & & $\stackrel{n}{\sim}$ & $\begin{array}{l}\text { స్ } \\
\text { ஸे }\end{array}$ & & & & & \\
\hline 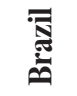 & & $\stackrel{n}{\sim}$ & $\frac{2}{0}$ & & & & & & & $\underset{i}{i}$ & $\begin{array}{l}0 \\
\stackrel{2}{\sim}\end{array}$ & & & & & \\
\hline 茎 & & $\overrightarrow{0}$ & $\begin{array}{c}\tilde{n} \\
0\end{array}$ & & & & & & & $\begin{array}{l}0 \\
0\end{array}$ & $\begin{array}{l}n \\
0\end{array}$ & & & & & \\
\hline $\mathscr{\Omega}$ & & $\frac{d}{\dot{m}}$ & $\begin{array}{l}\infty \\
\dot{\alpha} \\
\alpha\end{array}$ & $\frac{}{6}$ & $\begin{array}{l}2 \\
\infty \\
\dot{+}\end{array}$ & $\begin{array}{l}\infty \\
\stackrel{\Delta}{\Delta}\end{array}$ & $\stackrel{n}{\stackrel{n}{0}}$ & 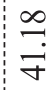 & & $\begin{array}{l}\vec{b} \\
\stackrel{\sim}{े}\end{array}$ & $\stackrel{n}{n}$ & 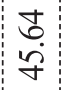 & $\begin{array}{l}\sigma \\
\dot{\sigma}\end{array}$ & $\overrightarrow{\widehat{\sigma}}$ & $\begin{array}{c}\stackrel{8}{0} \\
\text { ले }\end{array}$ & $\underset{\sim}{\nabla}$ \\
\hline 光 & & $\begin{array}{l}\infty \\
\infty \\
\infty \\
\sim\end{array}$ & $\begin{array}{l}0 \\
\stackrel{n}{0}\end{array}$ & $\begin{array}{l}\sigma \\
i\end{array}$ & $\stackrel{2}{0}$ & 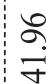 & $\stackrel{\sigma}{\Xi}$ & $\begin{array}{l}5 \\
\text { in }\end{array}$ & & $\begin{array}{l}\hat{\sigma} \\
\sim\end{array}$ & ○ & $\begin{array}{c}2 \\
\infty \\
n\end{array}$ & ণิ & $\begin{array}{l}\infty \\
\infty\end{array}$ & 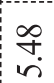 & $\widetilde{\Xi}$ \\
\hline 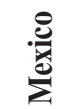 & & $\underset{\sim}{\infty} \underset{\sim}{\infty}$ & $\begin{array}{l}8 \\
0\end{array}$ & $\stackrel{0}{\circ}$ & 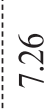 & F & $\stackrel{\text { r. }}{\oplus}$ & 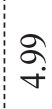 & & $\begin{array}{l}\stackrel{8}{0} \\
\stackrel{0}{ }\end{array}$ & $\begin{array}{l}8 \\
0\end{array}$ & $\frac{2}{6}$ & $\frac{0}{m}$ & 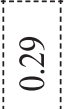 & $\tilde{n}$ & $\begin{array}{l}0 \\
\text { అె }\end{array}$ \\
\hline 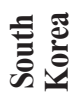 & & 8 & $\begin{array}{l}\widetilde{N} \\
0\end{array}$ & $\begin{array}{c}\Im \\
\gamma\end{array}$ & $\stackrel{゚}{\stackrel{0}{+}}$ & $\underset{r}{\mathscr{\sigma}}$ & $\stackrel{n}{\simeq}$ & $\begin{array}{l}\stackrel{8}{\circ} \\
\sigma\end{array}$ & & $\begin{array}{l}8 \\
0\end{array}$ & $\begin{array}{l}\infty \\
+\end{array}$ & $\begin{array}{c}\tilde{\sigma} \\
\dot{n}\end{array}$ & $\begin{array}{l}\sigma \\
\sigma\end{array}$ & $\begin{array}{c}2 \\
0 \\
0\end{array}$ & $\begin{array}{l}\infty \\
\stackrel{\infty}{2}\end{array}$ & 胥 \\
\hline 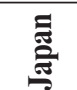 & & $\stackrel{8}{5}$ & $\begin{array}{l}6 \\
0\end{array}$ & $\begin{array}{c}n \\
n \\
n\end{array}$ & $\begin{array}{l}\infty \\
\stackrel{n}{n}\end{array}$ & in & $\begin{array}{l}6 \\
\pm \\
\end{array}$ & $\stackrel{\Im}{\stackrel{\lambda}{2}}$ & & $\begin{array}{l}\sigma \\
\infty \\
\infty\end{array}$ & $\begin{array}{l}n \\
0\end{array}$ & 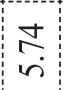 & 总 & $\begin{array}{c}0 \\
\infty \\
\infty\end{array}$ & $\stackrel{\nabla}{2}$ & مे \\
\hline 駦 & & 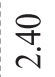 & 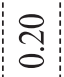 & $\begin{array}{l}n \\
\simeq \\
c\end{array}$ & $\underset{6}{\sigma}$ & $\stackrel{\infty}{\curvearrowright}$ & $\begin{array}{l}\infty \\
\stackrel{0}{0}\end{array}$ & 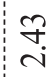 & & 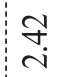 & $\begin{array}{l}\infty \\
-\end{array}$ & $\begin{array}{l}2 \\
\infty \\
\infty\end{array}$ & $\begin{array}{l}\infty \\
0\end{array}$ & $\begin{array}{l}n \\
\sim \\
\forall\end{array}$ & $\begin{array}{l}\infty \\
\text { 入 }\end{array}$ & 于 \\
\hline 哥 & & ठ઼. & $\begin{array}{c}\infty \\
\end{array}$ & $\begin{array}{l}\infty \\
\unlhd\end{array}$ & $\begin{array}{l}0 \\
\stackrel{ \pm}{ \pm}\end{array}$ & $\underset{\infty}{\underset{\infty}{\sigma}}$ & $\begin{array}{l}6 \\
\stackrel{0}{0}\end{array}$ & $\begin{array}{l}\tilde{} \\
\infty\end{array}$ & & $\begin{array}{l}\sigma \\
\infty \\
\infty\end{array}$ & 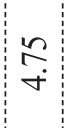 & $\begin{array}{l}0 \\
n \\
n\end{array}$ & $\begin{array}{c}\Omega \\
\sigma\end{array}$ & $\frac{}{6}$ & 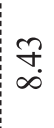 & $\underset{\sigma}{\approx}$ \\
\hline 异 & & $=$ & $\begin{array}{c}\overparen{1} \\
0\end{array}$ & $\begin{array}{l}\text { ปี } \\
6\end{array}$ & $\underset{\sigma}{\approx}$ & $\begin{array}{l}\widetilde{\sigma} \\
\underset{\sim}{ }\end{array}$ & $\vec{n}$ & ก̃ & & 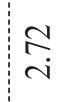 & ๓n & $\begin{array}{c} \pm \\
\infty\end{array}$ & 임 & $\begin{array}{l}\infty \\
\infty \\
\infty\end{array}$ & $\frac{9}{i}$ & तె \\
\hline 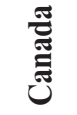 & & $\stackrel{\sim}{\underset{\sim}{\sim}}$ & $\begin{array}{c}\bar{\sigma} \\
i\end{array}$ & $\begin{array}{l}\sigma \\
\sigma\end{array}$ & $\stackrel{\tilde{n}}{\tilde{m}}$ & హे & $\stackrel{\bigcirc}{\stackrel{\circ}{i}}$ & $\begin{array}{l}\infty \\
\infty \\
\infty\end{array}$ & & $\stackrel{\infty}{\sim}$ & 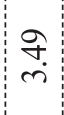 & 于 & $\begin{array}{l}\tilde{N} \\
\sim\end{array}$ & $\stackrel{?}{\Im}$ & 离 & $\stackrel{\overbrace{}}{=}$ \\
\hline 音 & 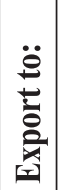 & 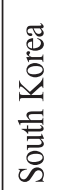 & 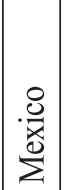 & 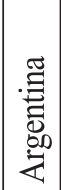 & 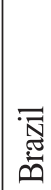 & $\begin{array}{l}00 \\
0 \\
0 \\
0 \\
00 \\
0 \\
0 \\
0\end{array}$ & 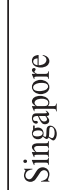 & 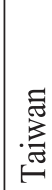 & 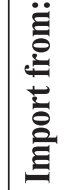 & 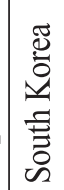 & 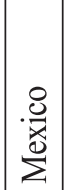 & 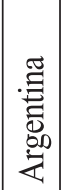 & 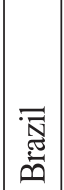 & $\mid \begin{array}{c}00 \\
0 \\
0 \\
0 \\
00 \\
0 \\
0 \\
0\end{array}$ & $\begin{array}{l}0 \\
\text { : } \\
\text { : } \\
\text { : } \\
\text { : }\end{array}$ & 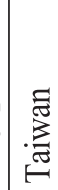 \\
\hline
\end{tabular}




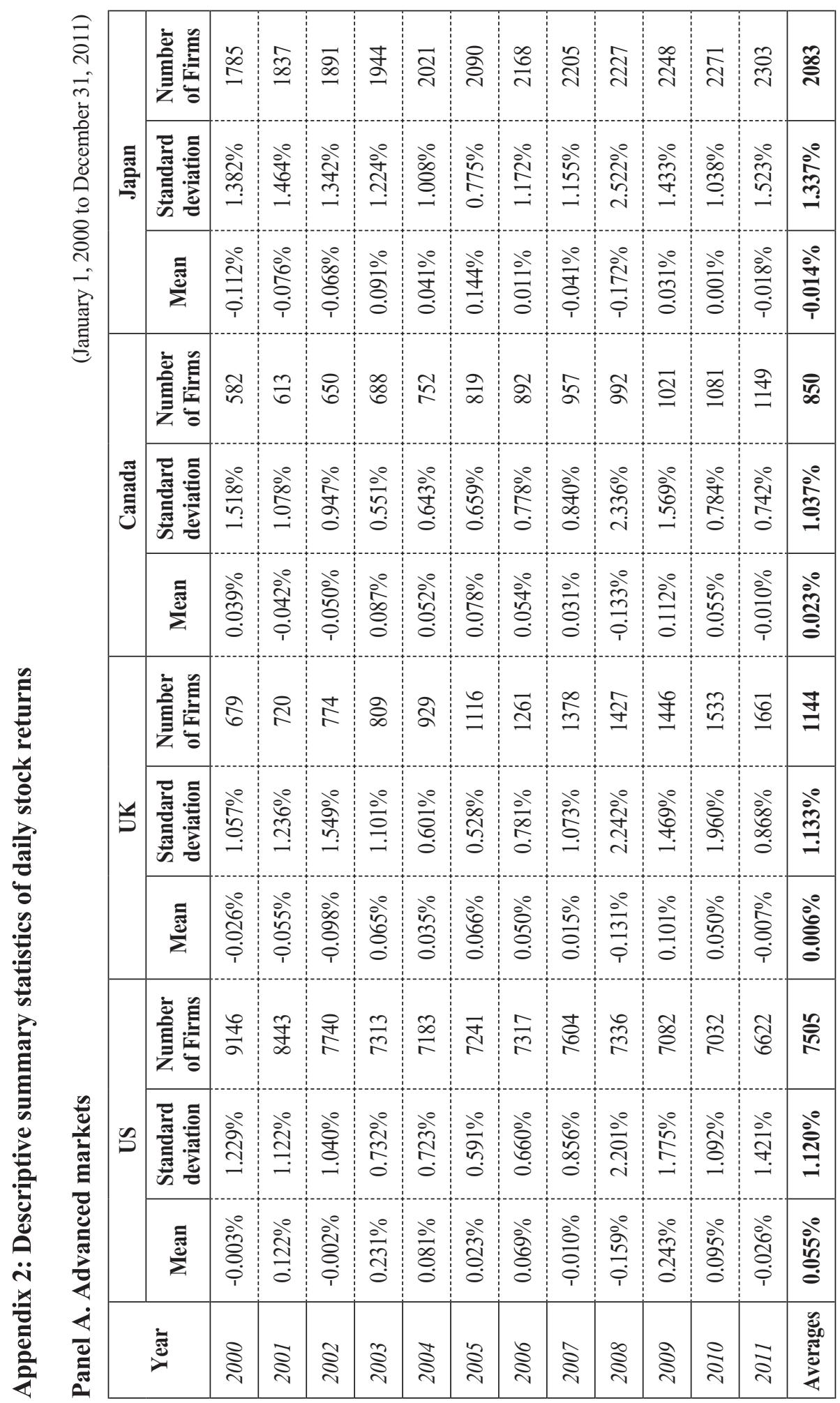




\begin{tabular}{|c|c|c|c|c|c|c|c|c|c|c|c|c|c|c|}
\hline \multirow{3}{*}{ 롶 } & 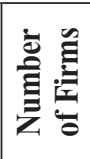 & $\stackrel{\infty}{\sim}$ & 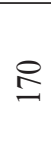 & $\stackrel{0}{ }$ & $\infty$ & $\infty$ & $\stackrel{\infty}{\varrho}$ & $\stackrel{\vec{\nu}}{ }$ & $\stackrel{?}{\sim}$ & ฟี & $\stackrel{\infty}{n}$ & $\bar{i}$ & $\stackrel{\circ}{\stackrel{0}{v}}$ & $\frac{n}{2}$ \\
\hline & 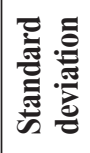 & $\begin{array}{l}\stackrel{\partial}{\pi} \\
\stackrel{?}{-}\end{array}$ & 命 & $\frac{\stackrel{\partial}{+}}{n}$ & $\begin{array}{l}\text { oे } \\
\stackrel{0}{0} \\
\text { రे }\end{array}$ & 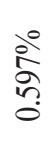 & 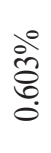 & $\frac{\stackrel{0}{2}}{\stackrel{0}{0}}$ & $\begin{array}{l}\text { ¿ें } \\
\text { ळे } \\
0\end{array}$ & $\begin{array}{l}\stackrel{0}{\circ} \\
\stackrel{0}{0} \\
\dot{i}\end{array}$ & 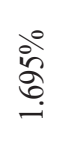 & ঐ̊ & $\begin{array}{l}\stackrel{0}{0} \\
\stackrel{\Xi}{\Xi}\end{array}$ & 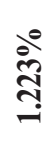 \\
\hline & $\sum_{\bar{E}}^{\bar{E}}$ & $\begin{array}{l}\dot{b}^{0} \\
0 \\
0\end{array}$ & $\frac{0^{0}}{0}$ & $\frac{0}{2}$ & $\begin{array}{l}\text { in } \\
\text { o. } \\
0\end{array}$ & $\frac{\partial}{5}$ & 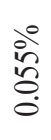 & 六 & 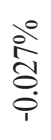 & 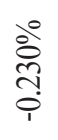 & $\begin{array}{l}\text { Oें } \\
\text { Oे. } \\
0\end{array}$ & 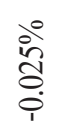 & 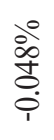 & $\frac{\stackrel{\partial}{0}}{\dot{\theta}}$ \\
\hline \multirow{3}{*}{ 惡 } & 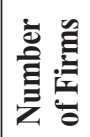 & $\tilde{\sigma}$ & $\overline{8}$ & $\vec{\delta}$ & $\underset{\sigma}{\infty}$ & $\stackrel{\rho}{\circ}$ & $\$$ & ชి & $\stackrel{0}{0}$ & $\stackrel{\circ}{\varrho}$ & 志 & $\stackrel{\Xi}{\Xi}$ & $\Xi$ & $\stackrel{\infty}{\infty}$ \\
\hline & 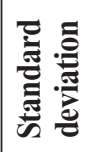 & $\stackrel{\partial}{\stackrel{7}{7}}$ & $\begin{array}{l}\frac{\infty}{\infty} \\
\stackrel{n}{n}\end{array}$ & 宊 & 离 & $\stackrel{\stackrel{ }{\hat{~}}}{\stackrel{0}{0}}$ & $\frac{\partial}{i n}$ & 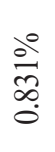 & $\begin{array}{l}\stackrel{0}{\circ} \\
\text { ळे } \\
0\end{array}$ & $\frac{\stackrel{0}{a}}{\stackrel{a}{i}}$ & $\begin{array}{l}\text { 仓ें } \\
\text { ڤ్ }\end{array}$ & $\stackrel{\partial}{\stackrel{\partial}{\sigma}}$ & $\frac{\partial}{a}$ & 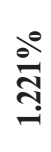 \\
\hline & 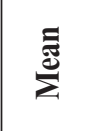 & $\begin{array}{l}\text { हें } \\
\text { हैं } \\
\text { iे }\end{array}$ & $\begin{array}{l}\stackrel{0}{0} \\
\stackrel{0}{0}\end{array}$ & $\frac{\stackrel{\circ}{0}}{\stackrel{0}{i}}$ & $\frac{\partial}{\equiv}$ & $\begin{array}{l}\stackrel{0}{0} \\
\text { ¿ें } \\
\dot{0}\end{array}$ & 仓ें & 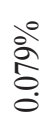 & $\begin{array}{l}80 \\
\stackrel{0}{0} \\
\text { हैं }\end{array}$ & $\frac{\stackrel{\circ}{\circ}}{\frac{1}{9}}$ & $\frac{\partial_{0}^{\circ}}{8}$ & $\frac{0_{0}^{\circ}}{8}$ & $\stackrel{\text { in }}{\text { iे }}$ & $\stackrel{\circ}{\stackrel{0}{0}}$ \\
\hline \multirow{3}{*}{ 总 } & 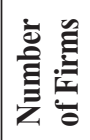 & $\vec{\sim}$ & 宲 & ? & $\stackrel{n}{n}$ & ळి & $\widehat{\widehat{ర}}$ & 志 & $\stackrel{g}{\mathbb{I}}$ & $\stackrel{8}{2}$ & $\stackrel{\infty}{\triangleright}$ & $\underset{\infty}{\bar{\infty}}$ & 京 & $\frac{N}{6}$ \\
\hline & 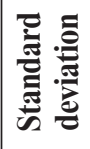 & ڤั & 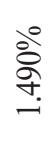 & $\frac{\stackrel{0}{2}}{a}$ & $\begin{array}{l}\stackrel{0}{\circ} \\
\text { ळे }\end{array}$ & 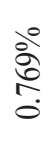 & $\frac{\stackrel{0}{0}}{0}$ & $\begin{array}{l}\dot{0} \\
\stackrel{0}{0} \\
0\end{array}$ & $\frac{\partial 0}{\partial}$ & 离 & 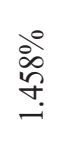 & ڤे & 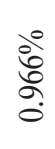 & $\stackrel{\stackrel{\circ}{\circ}}{\stackrel{\circ}{ }}$ \\
\hline & $\sum_{\Sigma}^{\bar{E}}$ & ठें & $\stackrel{\stackrel{0}{0}}{\stackrel{0}{0}}$ & 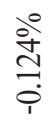 & 过 & 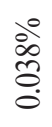 & $\begin{array}{l}\stackrel{0}{\circ} \\
\stackrel{0}{0} \\
0\end{array}$ & $\begin{array}{l}\dot{0} \\
\stackrel{0}{0} \\
0\end{array}$ & $\begin{array}{l}\stackrel{0}{0} \\
\stackrel{0}{0}\end{array}$ & $\begin{array}{l}\stackrel{0}{\infty} \\
\stackrel{\infty}{\circ} \\
\dot{1}\end{array}$ & $\begin{array}{l}\stackrel{0}{0} \\
\infty \\
0 \\
0\end{array}$ & $\stackrel{\text { in }}{\stackrel{0}{0}}$ & $\begin{array}{l}\stackrel{\circ}{0} \\
\dot{0}\end{array}$ & 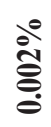 \\
\hline & $\bar{\tau}$ & $\underset{丶}{\stackrel{\Xi}{~}}$ & $\stackrel{\curvearrowright}{\curvearrowright}$ & 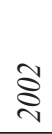 & $\stackrel{\curvearrowright}{\stackrel{2}{2}}$ & $\stackrel{\curvearrowright}{\curvearrowright}$ & $\stackrel{\overbrace{}}{\S}$ & 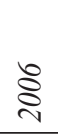 & 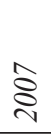 & $\underset{\sim}{\stackrel{\infty}{ి}}$ & $\underset{\hat{\Sigma}}{\stackrel{2}{2}}$ & $\underset{\sim}{\stackrel{\overbrace{}}{\imath}}$ & $\underset{\approx}{\Xi}$ & 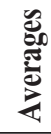 \\
\hline
\end{tabular}




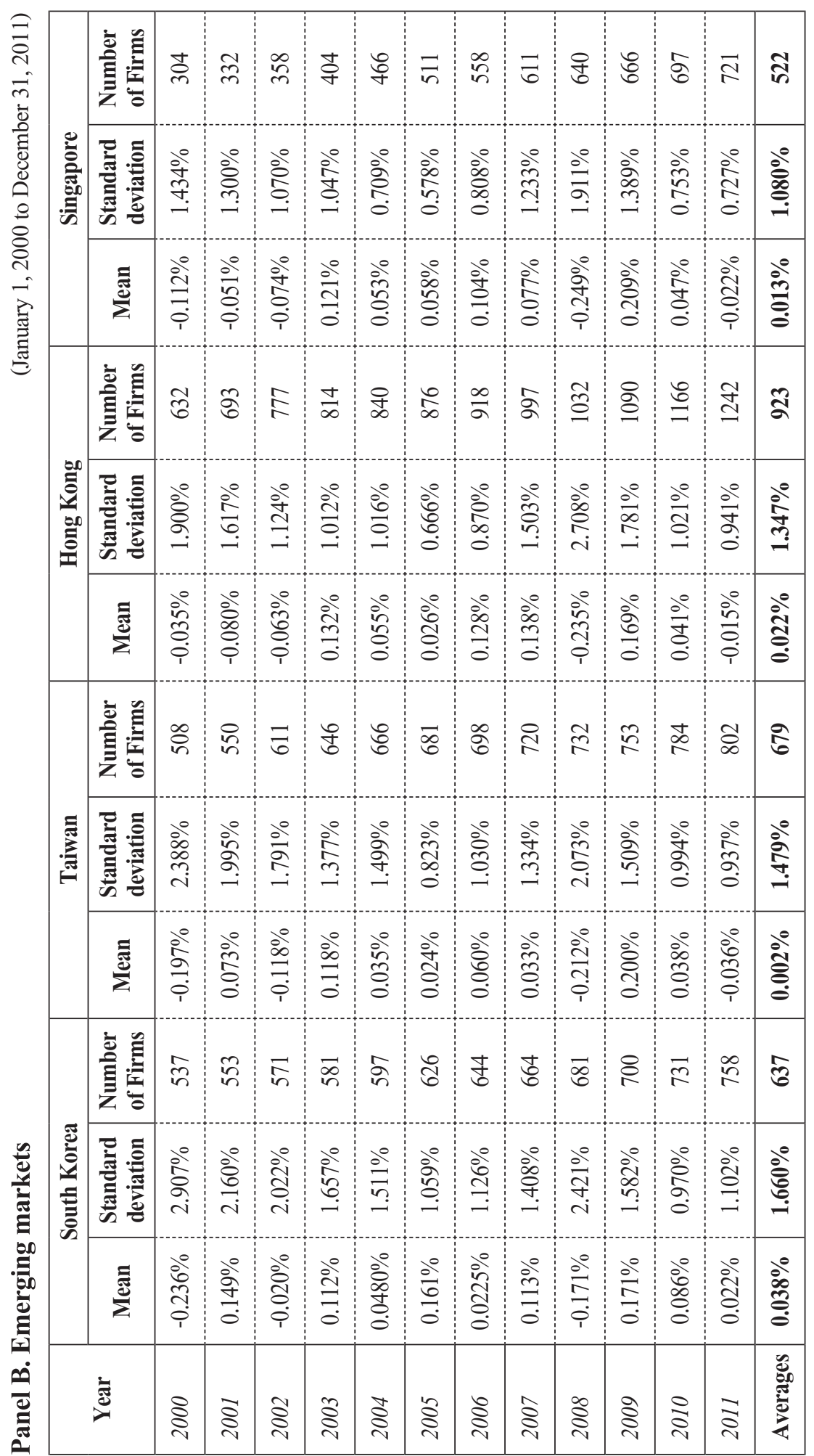


I

\begin{tabular}{|c|c|c|c|c|c|c|c|c|c|c|c|c|c|c|}
\hline & 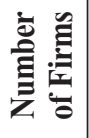 & $\infty$ & 声 & $\infty$ & $\tilde{\infty}$ & $\infty$ & a & $\stackrel{\infty}{\circ}$ & $\Xi$ & 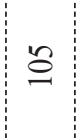 & 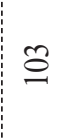 & 9 & $\stackrel{ \pm}{=}$ & $\approx$ \\
\hline & 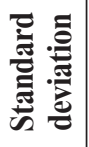 & 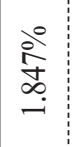 & $\stackrel{\circ}{\circ}$ & $\begin{array}{l}\stackrel{0}{\alpha} \\
\stackrel{\alpha}{-}\end{array}$ & 递 & $\frac{\stackrel{0}{0}}{\partial}$ & 岗 & ๙ે & $\frac{\circ}{5}$ & $\mid \begin{array}{c}\stackrel{0}{0} \\
0 \\
0 \\
-1\end{array}$ & จัे & $\begin{array}{l}\text { oें } \\
\text { cे } \\
\text { - }\end{array}$ & 离 & $\frac{\circ}{3}$ \\
\hline & $\bar{\Xi}$ & வั: & 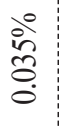 & $\frac{\partial}{0}$ & $\begin{array}{l}\text { సें } \\
\text { ¿े }\end{array}$ & $\frac{\partial}{\partial}$ & 总 & $\begin{array}{l}\stackrel{0}{\infty} \\
\stackrel{0}{0}\end{array}$ & $\frac{\circ}{8}$ & $\begin{array}{l}\stackrel{0}{\circ} \\
\stackrel{0}{0} \\
\stackrel{i}{0}\end{array}$ & 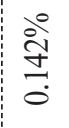 & $\begin{array}{c}0 \\
0 \\
0 \\
0\end{array}$ & oे & 兽 \\
\hline & 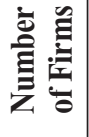 & $\stackrel{\infty}{q}$ & \& & $\stackrel{i}{n}$ & in & 5 & 8 & 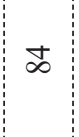 & I & 打 & $\stackrel{\circ}{\circ}$ & \pm & $\stackrel{ \pm}{ \pm}$ & $\cong$ \\
\hline & 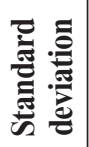 & 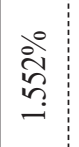 & 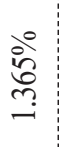 & ذి & $\begin{array}{l}\text { ळें } \\
\text { ळे }\end{array}$ & dें & बें & 今े & 产 & 递 & సेํํ & $\stackrel{\circ}{3}$ & $\begin{array}{l}0 \\
\dot{0} \\
\dot{\alpha} \\
0\end{array}$ & 产 \\
\hline & สิ & $\begin{array}{l}0 \\
\dot{0} \\
\dot{i}\end{array}$ & $\begin{array}{l}\stackrel{0}{\circ} \\
\vec{\partial} \\
\dot{0}\end{array}$ & $\begin{array}{l}\infty \\
0 \\
0 \\
i\end{array}$ & 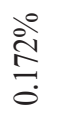 & 辛 & $\begin{array}{l}\text { 总 } \\
\text { oे } \\
\end{array}$ & $\frac{\partial}{3}$ & $\stackrel{2}{\stackrel{2}{5}}$ & $\begin{array}{c}\stackrel{0}{0} \\
0 \\
\\
\end{array}$ & $\frac{0}{0}$ & 高 & के & 突 \\
\hline & 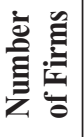 & 8 & 8 & 8 & $\approx$ & 8 & 8 & 8 & 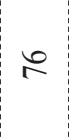 & $\therefore$ & $\cong$ & $\therefore$ & I & $F$ \\
\hline & 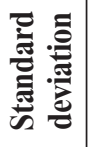 & 客 & 㐫 & 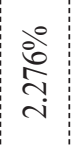 & 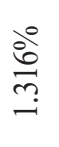 & $\stackrel{\frac{0}{2}}{\circ}$ & 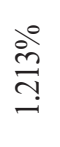 & $\begin{array}{l}0 \\
0 \\
o \\
o\end{array}$ & $\stackrel{\circ}{\circ}$ & $\stackrel{\circ}{\infty}$ & $\stackrel{0}{-}$ & $\stackrel{\circ}{\stackrel{\circ}{\perp}}$ & $\stackrel{\circ}{\stackrel{\circ}{\rightarrow}}$ & 高 \\
\hline & Еี & \begin{tabular}{l} 
के \\
\multirow{3}{0}{}
\end{tabular} & iे & $\frac{\stackrel{0}{0}}{2}$ & 0 & 总 & 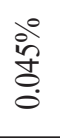 & $\begin{array}{c}\text { oे } \\
\vdots \\
0\end{array}$ & 㐫 & 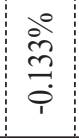 & $\frac{\mathrm{o}^{\circ}}{0}$ & 仓े & ì & $\begin{array}{l}\stackrel{\circ}{0} \\
\stackrel{8}{0}\end{array}$ \\
\hline & & t & & & & §ั่ & & ¿̊̀̆ & & ¿্口 & $\widetilde{N}$ & $\stackrel{\Xi}{\stackrel{\sim}{~}}$ & $\approx$ & \\
\hline
\end{tabular}

范 全

密

$\stackrel{2}{\exists}$

政

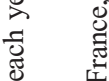

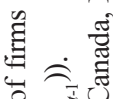

पि

造

言主离

$\pm 5_{00}^{-1}$

릉

ติ 11 ే

总必吾

龸洔

를

歌.

氖的

घथ

总

产

范热

元 离

$D_{80}^{\circ}$

क्षै

离

ऽ ए

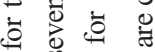

赵

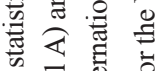

就离

है

के छ

क ज

灵

귱

ชु है ठี

要

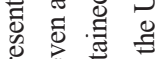

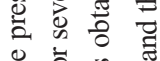

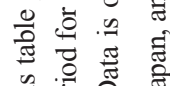

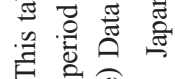

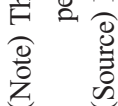




\section{Appendix 3: Data sources}

For the US market, we collect data on stock price, trading volume, and market capitalization of all firms listed on the NYSE, AMEX, and NASDAQ using the Center for Research in Security Prices (CRSP) database. We obtain book values for each firm from the Compustat database. Fama-French risk factors are taken from the French Data Library. ${ }^{14}$ For all other markets except the US, we collect data on stock price, trading volume, market capitalization, and book-to-market value of all firms from DataStream International.

\section{Appendix 4: Portfolio variable formation}

The formation of size, book-to-market, momentum and illiquidity portfolios follows the criteria in the study by Fama and French (1993). Portfolios are formed on the first day of every month and cover one-month periods from the first trading day of the month to the last trading day of the month. To form portfolios, all firms must have book value data for December in year $t-1$ and equity data (stock price and market capitalization) from the starting date of year $t$. We divide portfolios in the sample into five sizes (large/ small market capitalization), five book-to-market ratios (high/low), five momentums (winner/loser), and five Amihud (2002) illiquidity measures (illiq/liq).

To construct the size variable $\left(S M B_{t}\right)$, we use the lowest-quintile (smallest) market value stocks portfolio return minus the highest-quintile (largest) market value stocks portfolio return for a given day. To construct the book-to-market variable $\left(H M L_{t}\right)$, we use the highest- quintile book-to-market value stocks portfolio return minus the lowestquintile book-to-market value stocks portfolio return for a given day. To construct the momentum variable $\left(M O M_{t}\right)$, we use the past six months' winner stocks (highest quintile) portfolio return minus past six months' loser stock (lowest quintile) portfolio return for a given day. To construct the illiquidity risk variable (Illiq ${ }_{t}$ ), we first calculate stocks illiquidity according to Amihud (2002) and then we use the most illiquid stocks portfolio return minus the most liquid stocks portfolio returns for a given day. All portfolio returns are calculated as the equally weighted returns.

\footnotetext{
${ }^{14} \mathrm{http}: / /$ mba.tuck.dartmouth.edu/pages/faculty/ken.french/data_library.html
} 